\title{
Fragment-Based Approach to Targeting Inosine-5'-monophosphate Dehydrogenase (IMPDH) from Mycobacterium tuberculosis
}

Ana Trapero, ${ }^{\dagger}$ Angela Pacitto, ${ }^{\dagger}$ Vinayak Singh, ${ }^{\S, \#}$ Mohamad Sabbah, $^{\dagger}$ Anthony G. Coyne, ${ }^{\dagger}$

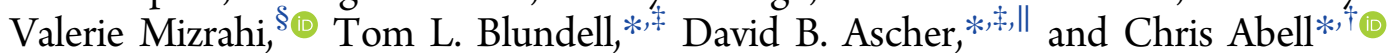

${ }^{\dagger}$ Department of Chemistry, University of Cambridge, Lensfield Road, Cambridge CB2 1EW, United Kingdom

${ }^{\ddagger}$ Department of Biochemistry, University of Cambridge, 80 Tennis Court Road, Cambridge CB2 1GA, United Kingdom

${ }^{\S}$ MRC/NHLS/UCT Molecular Mycobacteriology Research Unit \& DST/NRF Centre of Excellence for Biomedical TB Research, Institute of Infectious Disease and Molecular Medicine and Division of Medical Microbiology, Faculty of Health Sciences, University of Cape Town, Rondebosch 7701, Cape Town, South Africa

"Department of Biochemistry and Molecular Biology, Bio21 Institute, University of Melbourne, 30 Flemington Road, Parkville, Victoria 3052, Australia

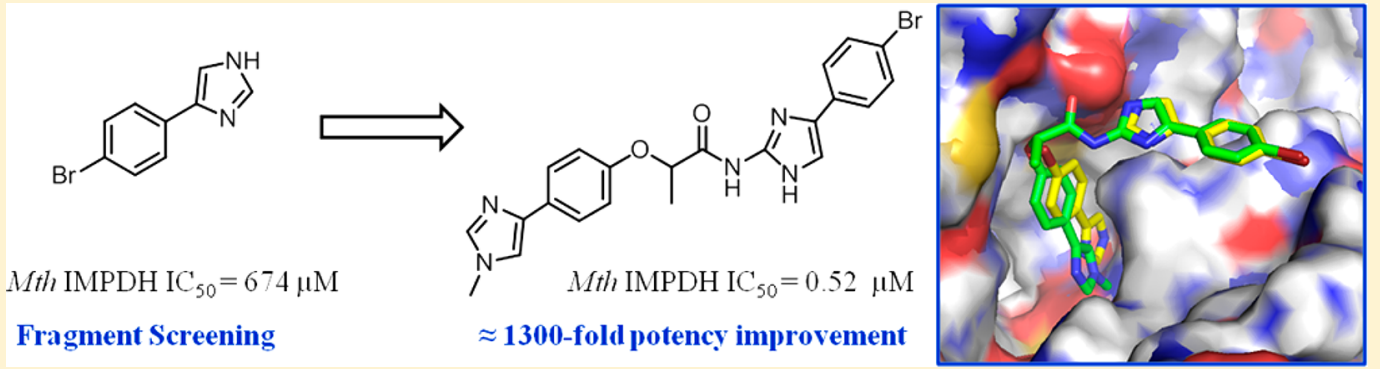

ABSTRACT: Tuberculosis (TB) remains a major cause of mortality worldwide, and improved treatments are needed to combat emergence of drug resistance. Inosine 5'-monophosphate dehydrogenase (IMPDH), a crucial enzyme required for de novo synthesis of guanine nucleotides, is an attractive TB drug target. Herein, we describe the identification of potent IMPDH inhibitors using fragment-based screening and structure-based design techniques. Screening of a fragment library for Mycobacterium thermoresistible (Mth) IMPDH $\Delta \mathrm{CBS}$ inhibitors identified a low affinity phenylimidazole derivative. X-ray crystallography of the Mth IMPDH $\triangle \mathrm{CBS}-\mathrm{IMP}$-inhibitor complex revealed that two molecules of the fragment were bound in the NAD binding pocket of IMPDH. Linking the two molecules of the fragment afforded compounds with more than 1000-fold improvement in IMPDH affinity over the initial fragment hit.

\section{INTRODUCTION}

Tuberculosis (TB) is a contagious infectious disease caused by Mycobacterium tuberculosis (Mtb), which can be transmitted through the air as droplets. The infection predominantly affects the lungs, but it can spread to other parts of the body, especially in patients with a suppressed immune system.

The World Health Organization (WHO) has estimated that nearly one-third of the world's population is infected with Mtb, leading to 1.8 million TB deaths in 2015. ${ }^{1}$ Although there has been a slow decline in new TB cases and TB-related deaths in recent years, the emergence and spread of multidrug resistant (MDR) and extensively drug resistant (XDR) strains of $M t b$ has increased the threat that this disease poses for global public health. According to the WHO, approximately 480,000 cases of MDR-TB emerged in 2015, and the cure rate of those patients was only $50 \%$.

Current TB treatments require combinations of four first-line drugs, isoniazid, rifampicin, ethambutol, pyrazinamide, and streptomycin, which must be taken for six months or longer. ${ }^{2}$
Resistant strains are not susceptible to the standard drugs, and although MDR-TB is treatable using second-line drugs, such treatments have a number severe side effects. ${ }^{3}$ Consequently, there is an urgent need for the development of novel and more effective drugs for the treatment of drug resistant TB.

Inosine-5'-monophosphate dehydrogenase (IMPDH, E.C. 1.1.1.205) has received considerable interest in recent years as an important target enzyme for immunosuppressive, ${ }^{4}$ anticancer, ${ }^{5,6}$ and antiviral drugs. ${ }^{7}$ Most recently, IMPDH has emerged as a promising antimicrobial drug target. ${ }^{8-11}$

IMPDH catalyzes the first unique step in the de novo synthesis of guanine nucleotides, the oxidation of inosine 5 '-monophosphate (IMP) to xanthosine 5 '-monophosphate (XMP) with the concomitant reduction of the cofactor nicotinamide adenine dinucleotide $\left(\mathrm{NAD}^{+}\right)$to $\mathrm{NADH}$ (Figure 1$) .{ }^{12} \mathrm{XMP}$ is then

Received: November 2, 2017

Published: March 16, 2018 


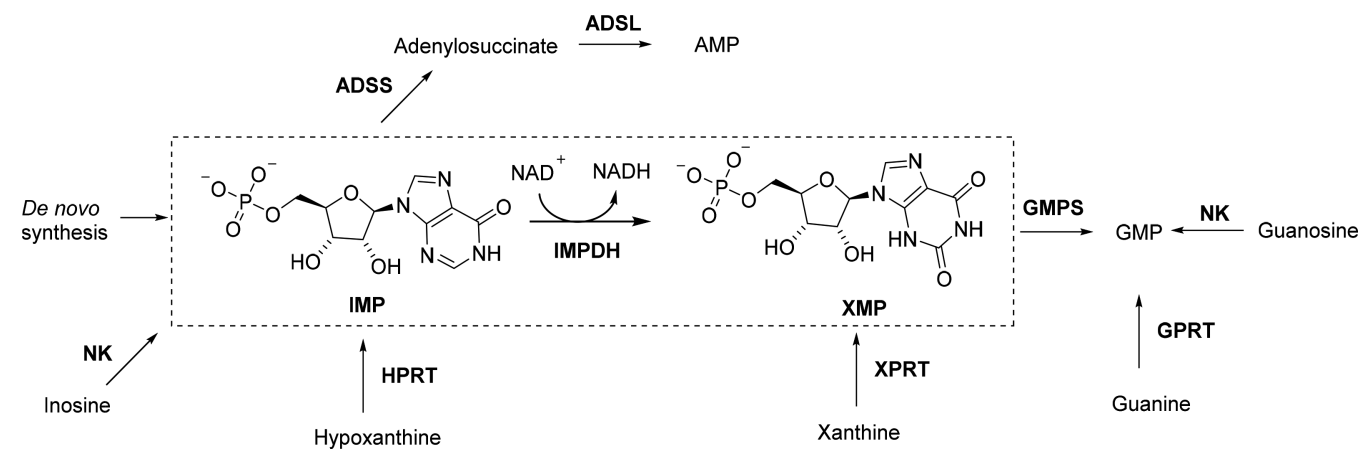

Figure 1. Purine nucleotide biosynthesis. The commonly occurring guanine nucleotide biosynthetic and salvage reactions are shown, as is the adenine nucleotide biosynthetic pathway. The IMPDH reaction is boxed. NK, nucleoside kinase; HPRT, hypoxanthine phosphoribosyl transferase; XPRT, xanthine phosphoribosyl transferase; GPRT, guanine phosphoribosyl transferase; GMPS, guanosine 5'-monophosphate synthetase; GMPR, guanosine 5 -monophosphate reductase; ADSS, adenylosuccinate synthetase; ADSL, adenylosuccinate lyase.

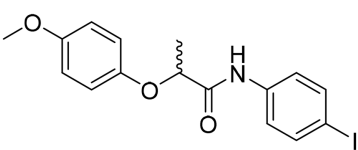

7759844 (1) (Ref 23) $\alpha K_{\mathrm{i}}=0.603 \mu \mathrm{M}(\mathrm{Mtb}$ IMPDH H37Rv) $\mathrm{MIC}=12.5 \mu \mathrm{M}$

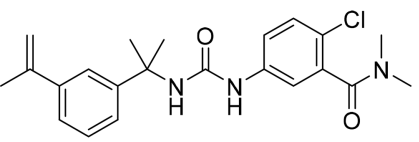

P41 (Ref 21)

$\alpha K \mathrm{i}=0.009 \mu \mathrm{M}($ Mtb IMPDH $\Delta \mathrm{CBS})$ $\mathrm{MIC}=5 \mu \mathrm{M}$

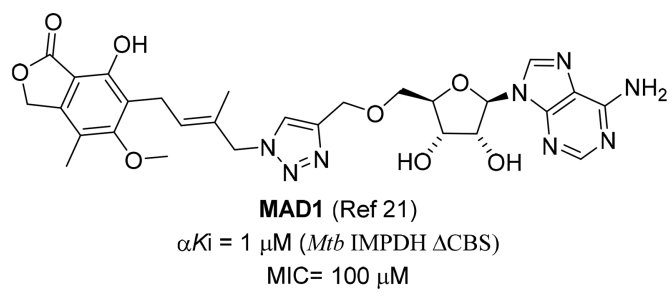

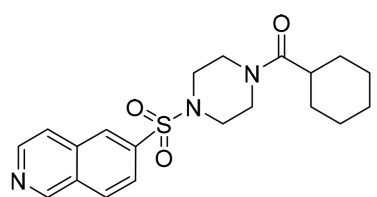

VCC234718 (Ref 25)

$\alpha K \mathrm{i}=0.12 \mu \mathrm{M}($ Mth IMPDH $\Delta \mathrm{CBS}) \quad \alpha K \mathrm{i}=0.22 \mu \mathrm{M}($ Mth $\mathrm{IMPDH} \Delta \mathrm{CBS})$ $\mathrm{MIC}=1.9 \mu \mathrm{M}$

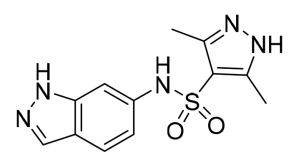

DDD00079282 (Ref 24)

$\mathrm{MIC}=2 \mu \mathrm{M}$

Figure 2. Structures of previously reported IMPDH inhibitors ( $\alpha \mathrm{K}_{\mathrm{i}}$ values against IMP). All compounds showed uncompetitive inhibition with respect to IMP.

subsequently converted to guanosine $5^{\prime}$-monophosphate (GMP) by a GMP synthetase. ${ }^{13}$

IMPDH has been deemed essential in every pathogen analyzed to date, including $M t b$, Staphylococcus aureus, and Pseudomonas aeruginosa, which are three of the most serious bacterial threats. ${ }^{14-16}$ However, this has been somewhat contradictory, ${ }^{17}$ in comparing cell versus animal work. IMPDH is an ubiquitous enzyme present in several eukaryotes, bacteria, and protozoa. ${ }^{18}$ The IMPDH reaction involves two chemical transformations. The first step of the IMPDH catalyzed reaction involves the attack of catalytic Cys on substrate IMP followed by hydride transfer to $\mathrm{NAD}^{+}$, forming the covalent enzyme intermediate E-XMP*. In the second step, E-XMP* is hydrolyzed to XMP. ${ }^{11}$ The enzyme exists in two different conformations, an open form that accommodates both the substrate and cofactor during the first step and a closed form where the active site flap moves into the $\mathrm{NAD}^{+}$-binding site for the E-XMP* hydrolysis. ${ }^{19}$

In recent years, there has been considerable effort aimed at identifying small molecule inhibitors of IMPDH as potential antitubercular agents. X-ray crystal structures of a truncated form of the $M t b$ enzyme in complex with some of these compounds have been reported. ${ }^{20-26}$

In antibacterial drug discovery, and especially in TB drug discovery, high-throughput screening (HTS) typically identifies a number of leads that show high potency in vitro, but most did not show any translation to an in vivo effect. It is also inevitable that the HTS libraries represent only a small fraction of possible chemical space and so limit confidence in finding a good starting point for subsequent development. Phenotypic screens can potentially lead to the identification of a molecule that modifies a disease phenotype by acting on a previously undescribed target or by acting simultaneously on more than one target. ${ }^{27}$ However, for many of these hits the relevant target or targets has not yet been identified, thus preventing further target-based optimization of the compounds. ${ }^{28,29}$

The previously reported IMPDH inhibitors, such as compounds 7759844 (1), MAD1, P41, VCC234718, and DDD00079282 (Figure 2), were identified by phenotypic screening or target based HTS of compound libraries. ${ }^{21,23-25}$

We have sought to develop IMPDH inhibitors using a fragment-based approach. Fragment-based drug discovery (FBDD) is now established in both industry and academia as an alternative approach to high-throughput screening for the generation of hits or chemical tools for drug targets. ${ }^{30}$

We have previously reported the discovery of several series of novel and potent inhibitors using FBDD to target $M t b$. Previously we have reported the fragment elaboration strategies that we have applied which have included fragment growing, merging, and linking. Although fragment linking is conceptually the most appealing strategy for fragment elaboration, in practice, 
Table 1. Structures and Activities for Compound 1 (7759844) and the Most Potent Fragment Hits Found in the Screen against Mth IMPDH $\triangle \mathrm{CBS}$

\begin{tabular}{|c|c|c|c|c|c|}
\hline Compd & Structure & $\begin{array}{c}\% \text { Inhibition } \\
\text { at } 1 \mathrm{mM}\end{array}$ & Compd & Structure & $\begin{array}{c}\% \text { Inhibition } \\
\text { at } 1 \mathrm{mM}\end{array}$ \\
\hline 1 & & $92 \pm 1^{a}$ & 11 & & $77 \pm 1$ \\
\hline 2 & & $65 \pm 2$ & 12 & & $64 \pm 6$ \\
\hline 3 & & $52 \pm 4$ & 13 & & $72 \pm 1$ \\
\hline 4 & & $59 \pm 1$ & 14 & & $86 \pm 6$ \\
\hline 5 & & $53 \pm 3$ & 15 & & $51 \pm 1$ \\
\hline 6 & $\mathrm{NH}_{2}$ & $50 \pm 3$ & 16 & & $88 \pm 10$ \\
\hline 7 & & $68 \pm 3$ & 17 & & $53 \pm 2$ \\
\hline 8 & & $57 \pm 1$ & 18 & & $79 \pm 4$ \\
\hline 9 & & $98 \pm 2$ & 19 & & $99 \pm 1$ \\
\hline 10 & & $66 \pm 1$ & & & \\
\hline
\end{tabular}

$a_{\%}$ Inhibition at $10 \mu \mathrm{M}$.

this strategy can be challenging where the choice of the optimal fragment linker can be crucial. ${ }^{31,32}$

In the fragment-based approach, biophysical techniques are usually used to identify small chemical compounds (fragments) that bind with low affinity to the drug target. X-ray crystallography is then usually employed to establish the binding mode of the fragment and to facilitate the design of elaborated fragments. The availability of high-resolution X-ray crystal structures of a truncated form of the IMPDH,,$^{21,24,25}$ in both the substrate-free and substrate/ligand-bound forms, makes this enzyme attractive for a fragment-based approach.

In this work, the discovery of a new class of potent $n M$ inhibitors of IMPDH using a FBDD approach is reported. A library of 960 fragments was screened against $M$ th IMPDH $\triangle \mathrm{CBS}$ using a biochemical assay. The fragment hits from this assay were examined using X-ray crystallography, and an X-ray crystal structure of one of the fragment complexes was solved to a resolution of $1.45 \AA$. Examination of the X-ray crystal structure suggested a strategy of fragment-linking for optimization of this fragment hit.

\section{RESULTS AND DISCUSSION}

Fragment Screening. An in-house fragment library composed of 960 fragments was screened using a biochemical assay against $M t h$ IMPDH $\Delta$ CBS. Mth IMPDH, which shares $85 \%$ sequence identity with $M t b$ IMPDH and is $100 \%$ identical in the active site, ${ }^{24,25}$ was chosen for the fragment screening and structural studies because it gave higher protein expression yields and better diffracting crystals than the $M t b$ orthologue. IMPDH activity was monitored spectrophotometrically by measuring the formation of $\mathrm{NADH}$ at $340 \mathrm{~nm}$. The biochemical assay was performed at a fragment concentration of $1 \mathrm{mM}$, and hits were retested in triplicate. Compound 1 (7759844) previously 
reported as IMPDH inhibitor was used as a positive control in assays (Table 1$).^{23}$

The screen resulted in 18 hits (1.9\% hit rate), where a hit was defined as a compound that gave greater than 50\% inhibition at a concentration of $1 \mathrm{mM}$. A complete list of fragment hits identified is included in Table 1. A number of common scaffolds were observed, in particular phenylimidazole (fragments 2-4), aminopyrazole (fragments 5-6), and naphthol (fragments 711), and the remaining compounds contained a substituted phenyl or a heterocyclic five membered ring (fragments 12-19).

The $\mathrm{IC}_{50}$ values of six of the most active fragments were measured and the $\mathrm{IC}_{50}$ and ligand efficiency (LE) values of these fragments are summarized in Table 2. The fragment screen

Table 2. $\mathrm{IC}_{50}$, Ligand Efficiency, and Alpha $K_{\mathrm{i}}$ Values of Fragment Hits and Compound 1 (7759844) against Mth IMPDH $\triangle \mathrm{CBS}$

\begin{tabular}{clll} 
Compd & $\mathrm{IC}_{50}(\mu \mathrm{M})(\mathrm{LE})^{a}$ & \multicolumn{1}{c}{$\mathrm{IMP} \alpha K_{\mathrm{i}}(\mu \mathrm{M})$} & \multicolumn{1}{c}{$\mathrm{NAD} \alpha K_{\mathrm{i}}(\mu \mathrm{M})$} \\
$\mathbf{1}$ & $0.77 \pm 0.06(0.40)$ & $0.86 \pm 0.03(\mathrm{UC})^{b}$ & $0.55 \pm 0.02(\mathrm{UC})$ \\
$\mathbf{2}$ & $674 \pm 53(0.36)$ & $609 \pm 3(\mathrm{UC})$ & $512 \pm 23(\mathrm{UC})$ \\
$\mathbf{1 1}$ & $336 \pm 6(0.39)$ & $361 \pm 53(\mathrm{UC})$ & $310 \pm 30(\mathrm{UC})$ \\
$\mathbf{1 4}$ & $400 \pm 7(0.42)$ & $238 \pm 6($ Mixed) & $262 \pm 39$ (UC) \\
$\mathbf{1 6}$ & $433 \pm 60(0.31)$ & $398 \pm 81$ (Mixed) & $525 \pm 64$ (UC) \\
$\mathbf{1 8}$ & $512 \pm 37(0.37)$ & $554 \pm 70$ (UC) & $452 \pm 26$ (UC) \\
$\mathbf{1 9}$ & $325 \pm 9(0.37)$ & $126 \pm 34$ (Mixed) & $355 \pm 47$ (UC)
\end{tabular}

${ }^{a}$ Ligand efficiency was calculated using the equation $\mathrm{LE}=(1.37 \times$ $\left.\mathrm{pIC}_{50}\right) / \mathrm{HA}$, where HA means heavy atom, i.e., a non-hydrogen atom. ${ }^{b}$ UC: Uncompetitive inhibition. provided an array of hits with $\mathrm{IC}_{50}$ ranging from $325 \mu \mathrm{M}$ to 674 $\mu \mathrm{M}$ and ligand efficiencies from 0.31 to 0.42 . The inhibition constant $\left[K_{\mathrm{i}}\right]$ with respect to both substrates IMP and $\mathrm{NAD}^{+}$was determined by assaying various concentrations of each inhibitor with five different concentrations of substrate and a fixed saturating concentration of the cosubstrate. The inhibition data for these fragments are summarized in Table 2. All compounds yielded an uncompetitive inhibition pattern with respect to $\mathrm{NAD}^{+}$with $K_{\mathrm{i}}$ values ranging from 262 to $525 \mu \mathrm{M}$. Fragments 14, 16 , and 19 yielded a mixed inhibition with respect to IMP with $K_{\mathrm{i}}$ values ranging from 126 to $398 \mu \mathrm{M}$, and compounds 1, 2, 11, and 18 yielded an uncompetitive inhibition with $K_{\mathrm{i}}$ values ranging from 361 to $609 \mu \mathrm{M}$.

Inhibition constants of compound 2 toward full-length $M t b$ IMPDH were also determined. Compound 2 inhibited fulllength $M t b$ IMPDH enzyme with a $K_{\mathrm{i}}$ value of $572 \pm 14 \mu \mathrm{M}$ with IMP as the substrate and a $K_{\mathrm{i}}$ value of $534 \pm 18 \mu \mathrm{M}$ with NAD as the substrate, which are similar to the $K_{\mathrm{i}}$ values observed for the Mth IMPDH $\triangle$ CBS enzyme.

X-ray Structure of Compounds 1 (7759844) and 2. Compound 1 and the six fragment hits $(2,11,14,16,18$, and 19) were selected for structural characterization using X-ray crystallography by soaking into preformed crystals of $\mathrm{Mth}$ IMPDH $\triangle \mathrm{CBS}$ as previously described. ${ }^{20}$ After molecular replacement, clear electron density was observed in the $2 F_{0}-$ $F_{\mathrm{c}}$ difference map $(\sigma=3.0)$ for IMP, and in addition density was observed for one molecule of compound $\mathbf{1}$ (Figure 3A) and two molecules of compound 2 (Figure $3 \mathrm{~B}$ ), which were partially occupying the $\mathrm{NAD}^{+}$binding site. None of the other fragments
A

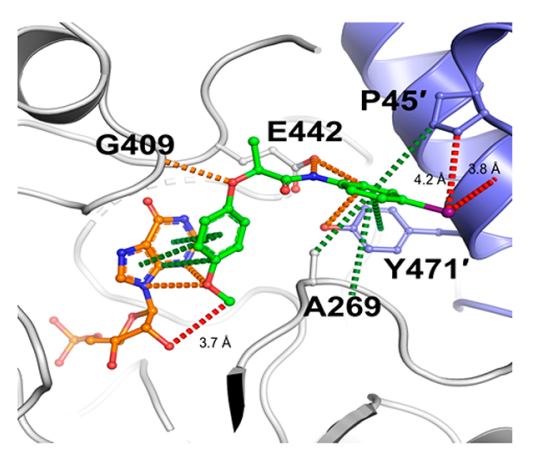

B

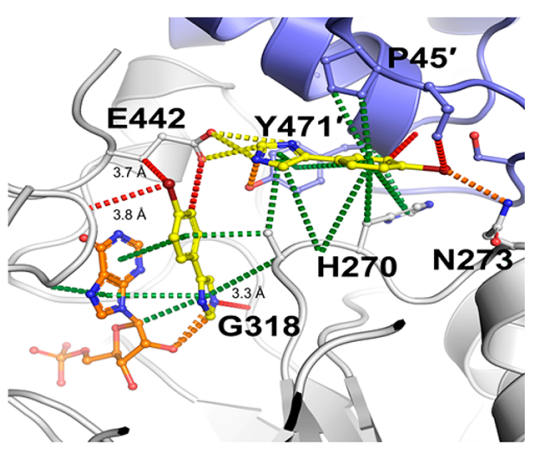

C

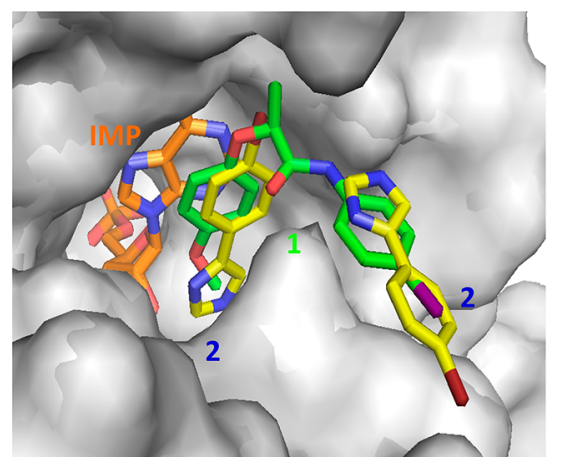

Figure 3. X-ray crystal structure of compounds $\mathbf{1}$ and $\mathbf{2}$ bound to Mth IMPDH $\Delta$ CBS. Ligand interactions are represented as dotted lines; hydrogen bonds are represented in red, polar interactions in orange, ionic interactions in yellow, and aromatic and $\pi$ interactions in green dotted lines. Proteinligand interactions were analyzed using Arpeggio. (a) Interactions made by $\mathbf{1}$ (green) in the X-ray crystal structure of the complex of IMPDH with IMP (orange). (b) Interactions made by 2 (yellow) in the X-ray crystal structure of the complex of IMPDH with IMP. (c) Structural alignment of the IMPDH crystal structures of $\mathbf{1}$ (green) and $\mathbf{2}$ (yellow). 
$(11,14,16,18$, and 19) showed any electron density in the X-ray crystal structures. Although the kinetic studies of compounds 1 and 2 suggested that these two compounds are uncompetitive with respect to $\mathrm{NAD}^{+}$, the binding mode of compounds $\mathbf{1}$ and $\mathbf{2}$ closely resembles that of other previously reported uncompetitive inhibitors of $M t b$ IMPDH. ${ }^{21,24,25}$ It has been proposed that the uncompetitive mode of inhibition of IMPDH inhibitors with respect to $\mathrm{NAD}^{+}$is consistent with their binding preferentially to the covalent IMPDH-XMP* intermediate after NADH has been released. $^{24,25,33}$

The structure of Mth IMPDH $\Delta \mathrm{CBS}$ with compound 1 showed that the inhibitor binds in the NAD pocket in a near identical manner to our recently described IMPDH inhibitors. $^{24,25}$ Compound $\mathbf{1}$ formed strong $\pi$ interactions with the hypoxanthine group of IMP, $\mathrm{P} 45^{\prime}, \mathrm{Y} 471^{\prime}$, and polar interactions with G409, E442, P45', and G470'. The electron density revealed two molecules of compound 2 within the NAD binding pocket of IMPDH. One molecule of compound 2 stacked with IMP, forming extensive $\pi$ interactions with the hypoxanthine group of IMP. This fragment was further stabilized through polar interactions, hydrogen bonds, and $\pi$ interactions to surrounding residues in the active site pocket, including A269, G318, and E442. The other molecule of compound 2 sits closer to the opening of the active site, making polar interactions with N273 and $\mathrm{E} 442$, and $\pi$ interactions with $\mathrm{H} 270$ and $\mathrm{Y}_{471}$.

A comparison of the structure of $M t h$ IMPDH $\Delta$ CBS with compound 1 with the fragment $\mathbf{2}$ structure shows that the two molecules of $\mathbf{2}$ mimic the position of the larger inhibitor 1 (Figure 3C).

Fragment Elaboration. Fragment 2 was selected as the starting point for exploration because of the ease of synthetic modification and the availability of a X-ray crystal structure to guide the optimization. For chemical elaboration of 2, fragment linking as well as fragment growing were considered. As the two molecules of fragment $\mathbf{2}$ are found to bind in adjacent regions of the target protein, the fragment-linking approach was the more attractive option. However, before fragment linking, fragment 2 was further optimized with the aim of improving the binding affinity. The structures and inhibitory activities of these compounds against $M$ th IMPDH $\triangle \mathrm{CBS}$ are summarized in Tables 3 and 4 . The corresponding data for fragment $\mathbf{2}$ have also been included for comparative purposes.

All compounds were evaluated at a concentration of $100 \mu \mathrm{M}$ with $M$ th IMPDH $\Delta$ CBS.

Fragment Growing. The fragment-growing strategy involves using structure-based drug design to form additional interactions by growing out from the starting fragment. Fragment 2 was modified at the 2-position of the imidazole ring to explore the introduction of various aromatic rings linked by a thioacetamide $(\mathbf{2 0 - 2 2})$ to form $\pi$ interactions with the hypoxanthine group of IMP (Figure S1). Such modifications gave compounds with improved $M t h$ IMPDH $\Delta$ CBS inhibition. The phenyl and benzofuran derivatives (20 and 21) showed 13 and $31 \%$ inhibition, respectively. Mth IMPDH $\Delta$ CBS inhibition was shown to be sensitive to minor modifications of the phenyl substituent groups; for example, the 4-iodo substituted $\mathbf{2 2}$ showed $30 \%$ inhibition at $100 \mu \mathrm{M}$, whereas the nonsubstituted compound, 20, showed $13 \%$ inhibition at the same concentration. The effect of the removal of the 4-bromo group was investigated and compounds 23-25 were synthesized. Removal of the bromo substituent in compounds 20-22 (13-31\% inhibition at $100 \mu \mathrm{M})$ was tolerated (23-25, 3-46\% inhibition at $100 \mu \mathrm{M})$. The importance of the aromatic amide linked by a
Table 3. Structures and Activities for Fragment 2 and Compounds 20-28 against $M t h$ IMPDH $\Delta$ CBS

(1)

thioacetamide was subsequently examined. Replacing the phenyl with isopropyl (26) resulted in complete loss of activity. Substitution of the thioacetamide by a thioacetic acid also led to a complete loss in activity (compounds 27 and 28).

Fragment Linking and SAR. Examination of the X-ray crystal structure of the previously reported inhibitor $\mathbf{1}$ when overlaid with fragment 2 revealed that the distance between the 4-position of the phenyl ring of fragment 2 and the 2-position of the imidazole ring represents the closest approach of the molecules (Figure S1). On the basis of this structural 
Table 4. Structures and Activities for Fragment 2 and Compounds 29-35 against Mth IMPDH $\Delta$ CBS

\begin{tabular}{|c|c|c|c|}
\hline Compd & Structure & $\begin{array}{c}\% \text { Inhibition } \\
\text { at } 100 \mu \mathrm{M}\end{array}$ & $\begin{array}{l}\mathrm{IC}_{50}(\mu \mathrm{M}) \\
(\mathrm{LE})^{a}\end{array}$ \\
\hline 2 & & $<5 \%$ & $\begin{array}{c}674 \pm 53 \\
(0.36)\end{array}$ \\
\hline 29 & & $20 \pm 5$ & $\mathrm{ND}^{b}$ \\
\hline 30 & & $56 \pm 11$ & $\begin{array}{l}58 \pm 8 \\
(0.21)\end{array}$ \\
\hline 31 & & $99 \pm 11^{c}$ & $\begin{array}{c}0.52 \pm 0.004 \\
(0.29)\end{array}$ \\
\hline 32 & & $24 \pm 1$ & ND \\
\hline 33 & & $83 \pm 2^{c}$ & $\begin{array}{c}2.21 \pm 0.08 \\
\quad(0.26)\end{array}$ \\
\hline 34 & & $4 \pm 1^{c}$ & ND \\
\hline 35 & & $97 \pm 1^{c}$ & $\begin{array}{c}0.47 \pm 0.03 \\
(0.34)\end{array}$ \\
\hline
\end{tabular}

${ }^{a}$ Ligand efficiency was calculated using the equation $\mathrm{LE}=\left(1.37 \times \mathrm{pIC}_{50}\right) / \mathrm{HA}$, where HA means heavy atom, i.e., a non-hydrogen atom. ${ }^{b} \mathrm{ND}$ : not determined. $\mathrm{IC}_{50}$ values were determined for compounds that showed $>50 \%$ inhibition. ${ }^{c} \%$ Inhibition at $10 \mu \mathrm{M}$.

information, three different linkers were designed to connect the two copies of the fragment 2 at these positions (compounds 2931). Initially, a thioacetamide and urea linker moieties were examined. Compounds 29 and 30 showed $20 \%$ and $56 \%$ of $M t h$ IMPDH $\Delta$ CBS inhibition, respectively, at $100 \mu \mathrm{M}$ (Table 4). Interestingly, compound $\mathbf{3 0}$ showed a 12 -fold improvement in
Mth IMPDH $\Delta$ CBS inhibitory activity with an $\mathrm{IC}_{50}$ of $58 \mu \mathrm{M}$, compared to the fragment 2 .

The lactate linker was then used, but all attempts to link 4phenylimidazole with 4-(4-bromophenyl)- $1 \mathrm{H}$-imidazole were unsuccessful. We therefore decided to synthesize compound 31, which contains 1-methyl-4-phenyl-1H-imidazole and 4-(4- 
bromophenyl)-1H-imidazole linked with a lactate analogue, as in compound 1. Compound 31 (Table 4) showed markedly improved Mth IMPDH $\Delta$ CBS inhibition with a LE of 0.29 and $\mathrm{IC}_{50}$ of $0.52 \mu \mathrm{M}$, which is 1300 -fold more potent compared to the fragment 2. Although compound 31 binds in the cofactor site, the mechanism of inhibition can vary depending on its relative affinities for the E-IMP and E-XMP* complexes. ${ }^{8,11}$ Kinetic evaluation of compound 31 showed the mode of $M$ th IMPDH $\Delta$ CBS inhibition was uncompetitive with respect to both IMP and the $\mathrm{NAD}^{+}$cofactor (see Figure S2, Supporting Information) with a $K_{\mathrm{i}}$ value of $0.30 \pm 0.02 \mu \mathrm{M}$ with IMP as the substrate and a $K_{\mathrm{i}}$ value of $0.20 \pm 0.01$ with $\mathrm{NAD}$ as the substrate.

Inhibition constants of compound 31 toward full-length $M t b$ IMPDH were also determined. Compound 31 inhibited fulllength $M t b$ IMPDH enzyme with a $K_{\mathrm{i}}$ value of $0.61 \pm 0.05 \mu \mathrm{M}$ with IMP as the substrate and a $K_{\mathrm{i}}$ value of $0.39 \pm 0.02 \mu \mathrm{M}$ with $\mathrm{NAD}$ as the substrate. The inhibition constants were consistent with the data using the Mth IMPDH $\triangle \mathrm{CBS}$ enzyme.

Removal of the bromo substituent in compound 29 to give compound 32 was well tolerated (Table 4). The importance of the imidazole group for the inhibitory activity against $M$ th IMPDH $\triangle$ CBS was confirmed by replacing of the 4-(4bromophenyl)-1H-imidazole substituent of compound 31 with 4-(4-bromophenyl)oxazole (33) which resulted in a 4-fold loss of activity (Table 4). Replacing the 4-(4-bromophenyl)-1Himidazole of 31 by a phenyl (34) resulted in complete loss of activity (Table 4). However, the 4-iodophenyl derivative 35 demonstrated slightly improved activity $\left(\mathrm{IC}_{50}=0.47 \mu \mathrm{M}, \mathrm{LE}=\right.$ $0.34)$ compared to compounds $31\left(\mathrm{IC}_{50}=0.52 \mu \mathrm{M}, \mathrm{LE}=0.29\right)$ and $1\left(\mathrm{IC}_{50}=0.77 \mu \mathrm{M}, \mathrm{LE}=0.40\right)$. It is noteworthy that $\mathrm{LE}$ of compound 35 was comparable to that of the original fragment hit $2(\mathrm{LE}=0.36)$ and other reported IMPDH inhibitors. ${ }^{34}$

The importance of the 4-bromo substituent on the phenyl ring in compound 31 was also explored (compounds 36-39, Table 5). Removal of the bromo substituent (36) resulted in a 5-fold loss in activity, whereas replacing this group with an iodine (39) or a morpholine ring (37) resulted in less than 1.3-fold loss in activity. The electronic nature of the substituent in this position had little effect on inhibitory activity. For example, an electrondonating methoxy (38) retained activity comparable to that of the bromine derivative (31). Among them, imidazoles 31, 3738, and 39 were found to be potent inhibitors of $M$ th IMPDH $\Delta$ CBS with $\mathrm{IC}_{50}$ values ranging from 520 to $690 \mathrm{nM}$.

The $(S)$-isomer of $\mathbf{3 1}$ was found to bind preferentially (Table $5)$, with the racemate $\mathbf{3 1}$ having approximately half the $M t h$ IMPDH $\triangle$ CBS inhibition of the $(S)$-isomer 31. This observation accords with the results previously reported for other series of IMPDH inhibitors. ${ }^{21,35}$

X-ray Structure of Compound 31. From crystals soaked with compound 31 , the $2 F_{0}-F_{c}$ difference map $(\sigma=3.0$ ) revealed strong density for the inhibitor. The structure of compound 31 (Figure 4A) showed that it bound in a nearly identical manner to compounds $\mathbf{1}$ and $\mathbf{2}$ in the NAD binding pocking (Figure 4B), stacking with IMP, and maintaining the interactions with $\mathrm{H} 270, \mathrm{~N} 273$, E442, and P45 and Y471 from the neighboring subunit. Compound $\mathbf{3 1}$ made additional interactions in the binding pocket, including polar interactions with D267 and N297.

Whole-Cell Activity against $M t b$. The whole-cell activity of the most potent analogues $31,33-39$, and $(S)-31$ in vitro was determined against $M t b \mathrm{H} 37 \mathrm{Rv}$ (see Table S1, Supporting Information). No significant inhibition of bacterial growth was detected for any of the compounds $\left(\mathrm{MIC}_{90} \geq 50 \mu \mathrm{M}\right)$ over the
Table 5. Structures and Activities for Compounds 31, 36-39, and (S)-31 against $M t h$ IMPDH $\Delta$ CBS

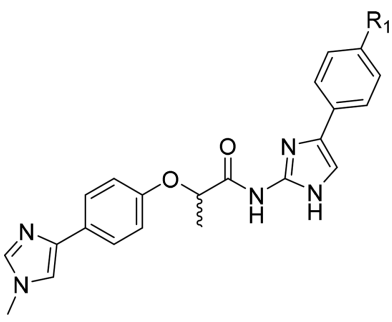

\begin{tabular}{|c|c|c|c|}
\hline Compd & $\mathrm{R}_{1}$ & $\begin{array}{c}\% \text { Inhibition } \\
\text { at } 10 \mu \mathrm{M}\end{array}$ & $\begin{array}{l}\mathrm{IC}_{50}(\mu \mathrm{M}) \\
(\mathrm{LE})^{a}\end{array}$ \\
\hline 31 & $\mathrm{Br}$ & $99 \pm 1$ & $\begin{array}{c}0.52 \pm 0.004 \\
(0.29)\end{array}$ \\
\hline 36 & $\mathrm{H}$ & $77 \pm 3$ & $\begin{array}{c}2.76 \pm 0.21 \\
(0.26)\end{array}$ \\
\hline 37 & $-N$ & $94 \pm 1$ & $\begin{array}{l}0.52 \pm 0.01 \\
\quad(0.24)\end{array}$ \\
\hline 38 & $\mathrm{OMe}$ & $95 \pm 1$ & $\begin{array}{c}0.64 \pm 0.03 \\
(0.27)\end{array}$ \\
\hline 39 & I & $96 \pm 1$ & $\begin{array}{c}0.69 \pm 0.06 \\
(0.28)\end{array}$ \\
\hline$(S)-31$ & $\mathrm{Br}$ & $99 \pm 1$ & $\begin{array}{c}0.27 \pm 0.02 \\
(0.30)\end{array}$ \\
\hline
\end{tabular}

${ }^{a}$ Ligand efficiency was calculated using the equation $\mathrm{LE}=(1.37 \times$ $\left.\mathrm{pIC}_{50}\right) / \mathrm{HA}$, where HA means heavy atom, i.e., a non-hydrogen atom.

tested concentration range $(0-100 \mu \mathrm{M})$. There are currently ongoing efforts to explain the lack of efficacy of the potent Mth IMPDH $\triangle$ CBS inhibitors described which could be caused by low membrane permeability, poor metabolic stability, and/or drug-efflux mechanisms.

Synthetic Chemistry. Compounds 20-29 and 32 were synthesized from 4-phenyl-1H-imidazole-2-thiol or 4-(4-bromophenyl)-1H-imidazole-2-thiol according to the sequence described in Scheme 1. Thioacetic derivatives 27 and 28 were prepared by treatment of 4-phenyl-1H-imidazole-2-thiol or 4-(4bromophenyl)- $1 \mathrm{H}$-imidazole-2-thiol with 2-chloroacetic acid in the presence of $\mathrm{NaOH}$ followed by neutralization with hydrochloric acid.

Thioacetamide 26 was synthesized by amide coupling between thioacetic derivative $\mathbf{2 8}$ and isopropylamine. Similarly, thioacetamides 20-25, 29, and 32 were prepared by cross-linking 4phenyl- $\mathrm{H}$-imidazole-2-thiol or 4-(4-bromophenyl)- $1 \mathrm{H}$-imidazole-2-thiol with $\alpha$-chloroacetamides 40-43, which were obtained by acylation of anilines with various substituents with chloroacetyl chloride.

The synthesis of urea $\mathbf{3 0}$ was achieved as shown in Scheme 2 by coupling amine 44 and $N$-(4-(1H-imidazol-4-yl)phenyl)- $1 H$ imidazole-1-carboxamide, which was obtained from commercially available 4-( $1 \mathrm{H}$-imidazol-4-yl)aniline as a crude intermediated, in the presence of $\mathrm{N}, \mathrm{N}$-diisopropylethylamine. Amine 44 was synthesized from benzyl ((5-(4-bromophenyl)- $1 \mathrm{H}$-imida- 
A

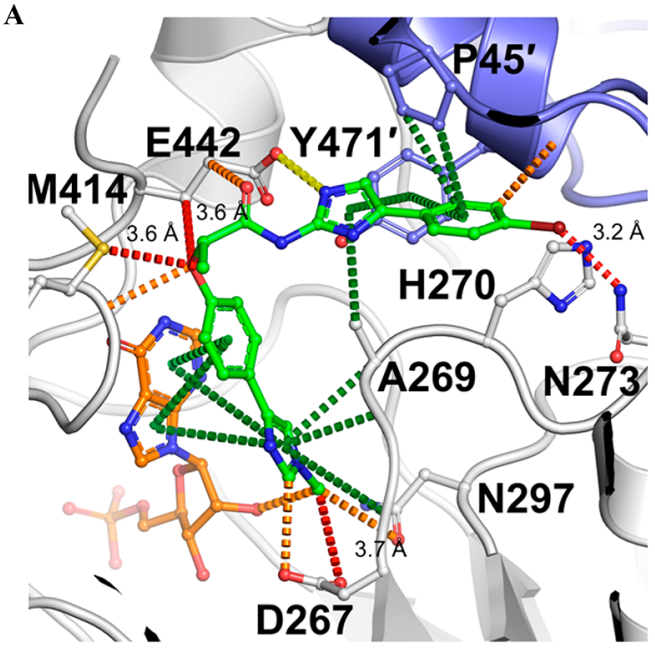

B

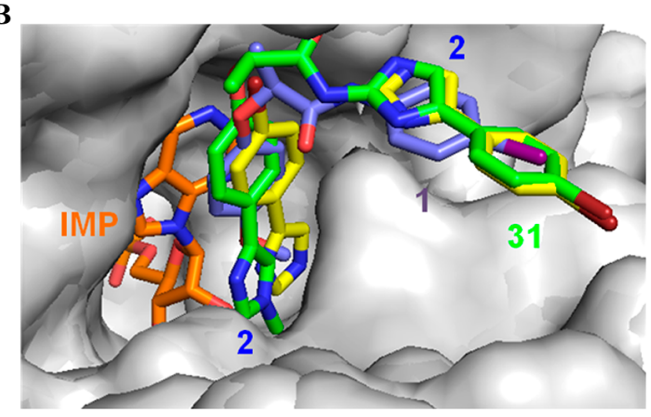

Figure 4. X-ray crystal structure of compound 31 bound to $M$ th IMPDH $\Delta$ CBS. Protein-ligand interactions were analyzed using Arpeggio. (a) Interactions made by 31 in the X-ray crystal structure of the complex of IMPDH with IMP (orange). Ligand interactions are represented as dotted lines; hydrogen bonds are represented in red, polar interactions in orange, ionic interactions in yellow, and aromatic and $\pi$ interactions in green dotted lines. (b) Structural alignment of the IMPDH crystal structures of $\mathbf{1}$ (lilac), $\mathbf{2}$ (yellow), and $\mathbf{3 1}$ (green).

zol-2-yl)methyl)carbamate, ${ }^{36}$ followed by the deprotection of the benzyloxycarbonyl group under acidic condition.
Imidazole derivatives 31, 36-38, and 39 were prepared following the synthetic procedure outlined in Scheme 3. 2Aminoimidazoles 50-54 were synthesized according to a published microwave-assisted protocol. ${ }^{37}$ In brief, 2-aminoimidazoles 50-54 were prepared by reaction of the commercially available $\alpha$-haloketones and $N$-acetylguanidine, followed by deacetylation (Scheme 3). Acid $\mathbf{5 9}$ was synthesized starting with imidazole 55, which was prepared by reaction of 2-bromo-4'hydroxyacetophenone with formamide as reported previously. ${ }^{38}$ The phenol $\mathbf{5 7}$ was synthesized by alkylation of imidazole $\mathbf{5 5}$, followed by deprotection of the methyl ether with $\mathrm{BBr}_{3}$. Substituted phenol $\mathbf{5 7}$ was converted to the ether $\mathbf{5 8}$ upon treatment with methyl 2-bromopropionate in the presence of $\mathrm{Cs}_{2} \mathrm{CO}_{3}$. Enantiomerically pure phenyl ethers were synthesized by using Mitsunobu reaction conditions with ethyl D-lactate (Scheme 4). After the hydrolysis of the ester group, the resulting carboxylic acid 59 was treated with thionyl chloride to give the acid chloride 60 , which was reacted with 2 -aminoimidazoles 5054 to afford imidazole derivatives 31, 36-38, and 39.

The syntheses of 2-acylaminooxazole 33 and amides 34-35 were achieved as shown in Scheme 5. 2-Acylaminooxazole derivative 33 was obtained by coupling the acid chloride derivative 60 with 2 -aminooxazole derivative 61 , which was prepared by reaction of 2,4'-dibromoacetophenone with urea. Similarly, amides 34-35 were prepared by coupling the corresponding anilines with the acid chloride derivative $\mathbf{6 0}$.

\section{CONCLUSIONS}

FBDD has emerged as a robust approach to identify small molecules that bind to a wide range of therapeutic targets. Fragment elaboration strategies have resulted in the development of a number of compounds that have progressed into clinical trials. Within the area of TB drug discovery, a number of HTS and phenotypic screens have been performed during the past decade. Although HTS identified a number of leads that show high potency in vitro, the translation to an in vivo effect has proven challenging.

Scheme 1. Synthesis of Thioacetamide and Thioacetic Derivatives 20-29 and $32^{a}$

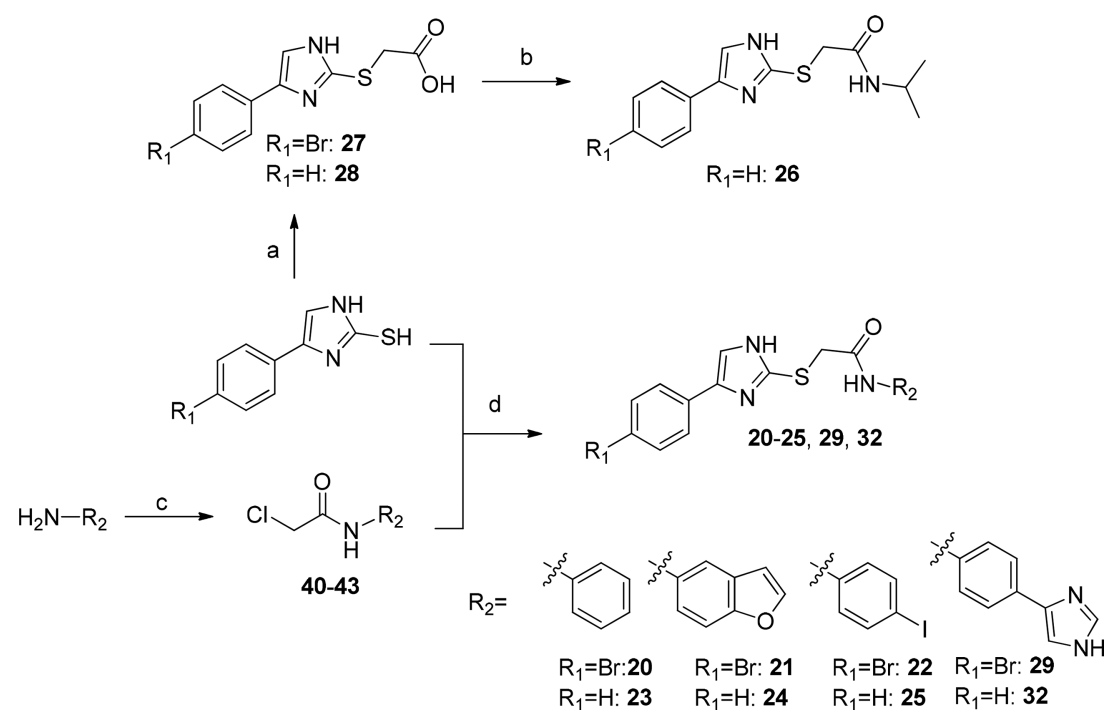

${ }^{a}$ Reagent and conditions: (a) 2-chloroacetic acid, $\mathrm{NaOH}, \mathrm{EtOH}, 8{ }^{\circ} \mathrm{C}, 69-72 \%$; (b) isopropylamine, HATU, DIPEA, EtOAc, rt, 73\%; (c) chloroacetyl chloride, TEA, DCM, rt, 89-99\%; (d) $\mathrm{NaOH}, \mathrm{MeOH}, \mathrm{H}_{2} \mathrm{O}, 70{ }^{\circ} \mathrm{C}, 69-96 \%$. 


\section{Scheme 2. Synthesis of Urea $30^{a}$}

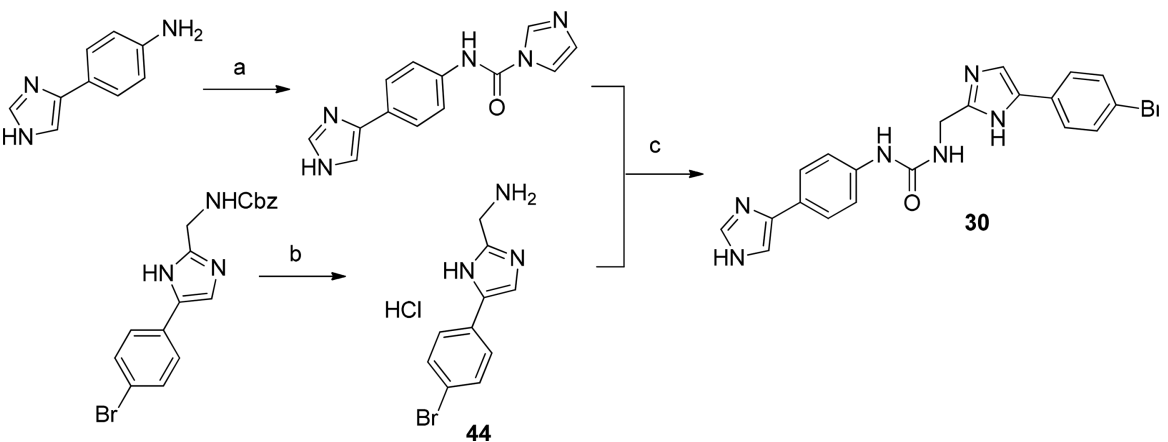

${ }^{a}$ Reagent and conditions: (a) CDI, THF, rt, quant.; (b) $\mathrm{HCl}(4 \mathrm{M})$, dioxane, $100{ }^{\circ} \mathrm{C}$, quant.; (c) DIPEA, DMF, rt, $26 \%$.

Scheme 3. Synthesis of 2-Acylaminoimidazole Derivatives $31,36-38$, and $39^{a}$

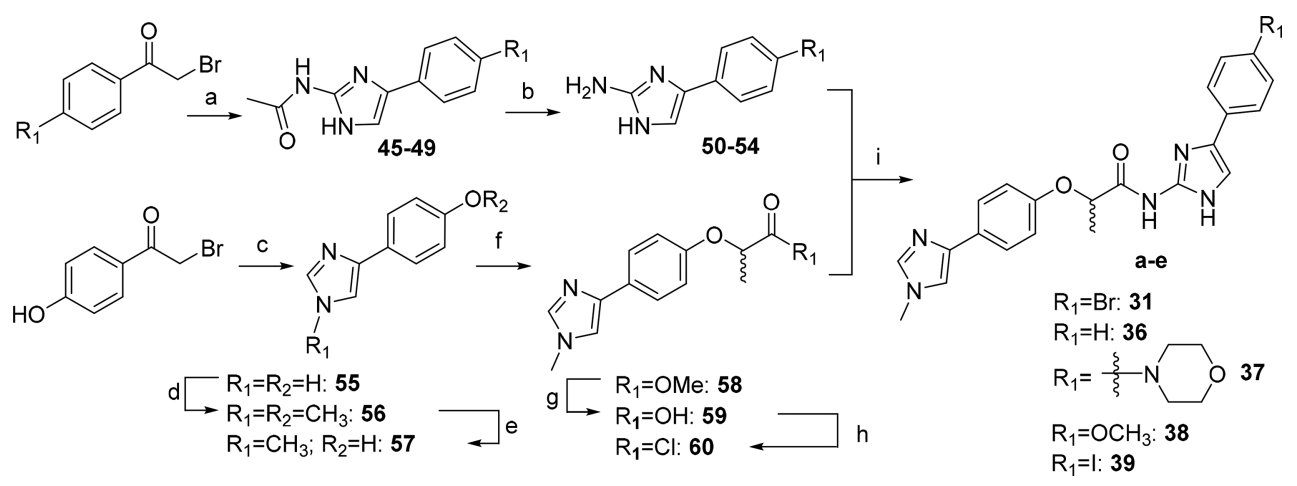

${ }^{a}$ Reagent and conditions: (a) acetylguanidine, $\mathrm{CH}_{3} \mathrm{CN}, \mu \mathrm{W}, 100{ }^{\circ} \mathrm{C}, 71-88 \%$; (b) (1) $20 \% \mathrm{H}_{2} \mathrm{SO}_{4}, \mathrm{MeOH}: \mathrm{H}_{2} \mathrm{O}(1: 1 \mathrm{v} / \mathrm{v}), \mu \mathrm{W}, 100{ }^{\circ} \mathrm{C}$; (2) aq $\mathrm{Na}_{2} \mathrm{CO}_{3}, 79-95 \%$; (c) formamide, $150{ }^{\circ} \mathrm{C}, 99 \%$; (d) $\mathrm{CH}_{3} \mathrm{I}, \mathrm{Cs}_{2} \mathrm{CO}_{3}$, DMF, rt, 88\%; (e) $\mathrm{BBr}_{3}$ (1 M in DCM), $-78^{\circ} \mathrm{C}_{\text {to rt, }} \mathrm{DCM}, 96 \%$; (f) $\mathrm{Cs}_{2} \mathrm{CO}_{3}$, methyl 2-bromopropionate, DMF, $60{ }^{\circ} \mathrm{C}, 92 \%$; (g) NaOH, THF: $\mathrm{H}_{2} \mathrm{O}(2: 1 \mathrm{v} / \mathrm{v}), 80{ }^{\circ} \mathrm{C}, 65 \%$; (h) $\mathrm{SOCl}_{2}, 80{ }^{\circ} \mathrm{C}$, quant.; (i) TEA, DCM, $40{ }^{\circ} \mathrm{C}, 61-$ $72 \%$.

Scheme 4. Synthesis of the $S$-Enantiomer of $31^{a}$

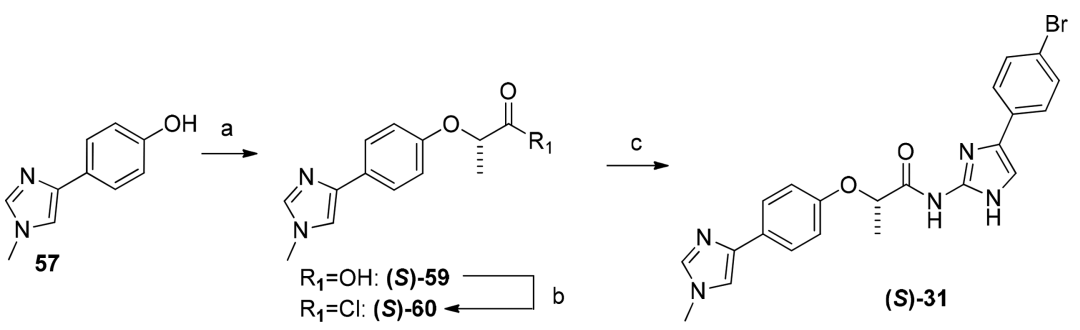

${ }^{a}$ Reagent and conditions: (a) (1) Ethyl D-lactate, $\mathrm{PPh}_{3}$, DEAD, THF, rt; (2) NaOH, THF: $\mathrm{H}_{2} \mathrm{O}(2: 1 \mathrm{v} / \mathrm{v})$, rt, $56 \%$; (b) $\mathrm{SOCl}_{2}, 80{ }^{\circ} \mathrm{C}$, quant.; (c) 50, TEA, DCM, $40{ }^{\circ} \mathrm{C}, 69 \%$.

This study illustrates the successful application of a fragmentbased approach followed by fragment optimization to obtain nanomolar affinity ligands of IMPDH. A library of 960 fragments were screened against $M t h$ IMPDH $\Delta \mathrm{CBS}$, and from the screen the phenylimidazole fragment hit $2\left(\mathrm{IC}_{50}=674 \mu \mathrm{M}\right)$ was identified. Kinetic experiments showed that $\mathbf{2}$ was an uncompetitive inhibitor of $M t h$ IMPDH $\Delta$ CBS with respect to $\mathrm{NAD}^{+}$and IMP. Two molecules of the fragment 2 were shown to bind at the NAD binding site of the enzyme. The X-ray crystal structure also revealed that one molecule of fragment 2 makes $\pi$ interactions with IMP and the other molecule sits closer to the opening of the active site, making polar interactions with N273 and $\mathrm{E} 442$ and $\pi$ interactions with $\mathrm{H} 270$ and $\mathrm{Y}_{471^{\prime}}$. This provides potential for further optimization of fragment 2 . To explore better the possibilities given by fragment 2 , fragment-linking and fragment-growing strategies were employed, resulting in low micromolar to nanomolar affinity compounds. Among them, compounds 31,35 , and $37-39$ were the most potent IMDPH inhibitors of the series described in this work with $\mathrm{IC}_{50}$ values between 0.47 and $0.69 \mu \mathrm{M}$, which represent $>1000$-fold improvement in $M t h$ IMPDH $\triangle$ CBS potency over the initial fragment hit. Compound 31 was shown to bind at the NAD binding site of the enzyme, and the X-ray crystal structure also revealed that it makes $\pi$ interactions with IMP, maintaining the interactions with $\mathrm{H} 270, \mathrm{~N} 273, \mathrm{E} 442$, and P45 and Y471 from the neighboring subunit. Moreover, compound 31 made additional interactions in the binding pocket, including polar interactions with D267 and N297. A comparison of this structure with the fragment $\mathbf{2}$ structure shows that the two molecules of $\mathbf{2}$ mimic the position of the larger inhibitor 31. This is the first example of 
Scheme 5. Synthesis of 2-Acylaminooxazole Derivative 33 and Amides 34-35

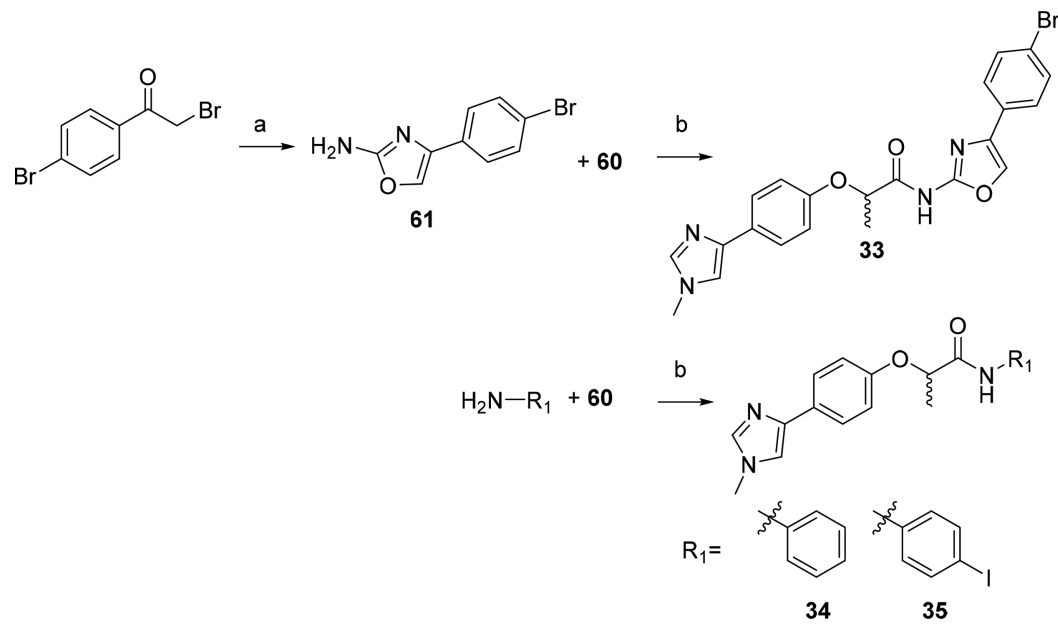

${ }^{a}$ Reagent and conditions: (a) urea, $\mathrm{CH}_{3} \mathrm{CN}, 80{ }^{\circ} \mathrm{C}, 78 \%$; (b) TEA, DCM, rt (for 34 and 35 ) or $40{ }^{\circ} \mathrm{C}$ (for 33), 64-76\%.

utilizing the fragment-based approach specifically to identify new potent inhibitors of IMPDH. Further structural optimization to improve the cellular activity of these analogues is ongoing with the aim of developing novel classes of anti-TB agents.

\section{EXPERIMENTAL SECTION}

1. Chemistry. 1.1. General Experimental Methods. Solvents were distilled prior to use and dried by standard methods. Unless otherwise stated, ${ }^{1} \mathrm{H}$ and ${ }^{13} \mathrm{C}$ NMR spectra were obtained in $\mathrm{CDCl}_{3}, \mathrm{MeOD}$, or DMSO- $d_{6}$ solutions using either a Bruker $400 \mathrm{MHz}$ AVANCE III HD Smart Probe, $400 \mathrm{MHz}$ QNP cryoprobe, or $500 \mathrm{MHz}$ DCH cryoprobe spectrometer. Chemical shifts $(\delta)$ are given in $\mathrm{ppm}$ relative to the residual solvent peak $\left(\mathrm{CDCl}_{3}:{ }^{1} \mathrm{H}, \delta=7.26 \mathrm{ppm} ;{ }^{13} \mathrm{C}, \delta=77.16 \mathrm{ppm}\right)$, and the coupling constants $(J)$ are reported in hertz $(\mathrm{Hz})$. Optical rotations were measured on a PerkinElmer Polarimeter 343 at $589 \mathrm{~nm}$ ( $\mathrm{Na} \mathrm{D}$-line), and specific rotations are reported in $10^{-1} \mathrm{deg} \mathrm{cm}^{2} \mathrm{~g}^{-1}$. Microwave reactions were performed using a Biotage Initiator system under reaction conditions as indicated for each individual reaction.

Reactions were monitored by TLC and LCMS to determine consumption of starting materials. Flash column chromatography was performed using an Isolera Spektra One/Four purification system and the appropriately sized Biotage SNAP column containing KP-silica gel $(50 \mu \mathrm{m})$. Solvents are reported as volume/volume eluent mixture where applicable.

High resolution mass spectra (HRMS) were recorded using a Waters LCT Premier Time of Flight (TOF) mass spectrometer or a Micromass Quadrapole-Time of Flight (Q-TOF) spectrometer.

Liquid chromatography mass spectrometry (LCMS) was carried out using an Ultra Performance Liquid Chromatographic system (UPLC) Waters Acquity H-class coupled to a Waters SQ Mass Spectrometer detector. Samples were detected using a Waters Acquity TUV detector at 2 wavelengths ( 254 and $280 \mathrm{~nm}$ ). Samples were run using an Acquity UPLC HSS column and a flow rate of $0.8 \mathrm{~mL} / \mathrm{min}$. The eluent consisted of $0.1 \%$ formic acid in water (A) and acetonitrile (B); gradient, from $95 \%$ A to $5 \%$ A over a period of 4 or $7 \mathrm{~min}$.

All final compounds had a purity greater than $95 \%$ by LCMS analysis. General Method A: Synthesis of Thioacetamides 20-25, 29, and 32. To a solution of the 2-chloroacetamide derivative $(0.17 \mathrm{mmol})$ in $\mathrm{MeOH}(8 \mathrm{~mL})$ was added 4-(4-bromophenyl)- $1 \mathrm{H}$-imidazole-2-thiol or 4-phenyl-1 $\mathrm{H}$-imidazole-2-thiol $(0.17 \mathrm{mmol})$, followed by a solution of $\mathrm{NaOH}(0.67 \mathrm{mmol})$ in $\mathrm{H}_{2} \mathrm{O}(2.5 \mathrm{~mL})$. The reaction mixture was stirred at $70{ }^{\circ} \mathrm{C}$ for $3 \mathrm{~h}$. After cooling to rt, the solvents were removed in vacuo and the resulting residue was taken up in $30 \mathrm{~mL}$ of EtOAc and washed with $\mathrm{H}_{2} \mathrm{O}(15 \mathrm{~mL})$. The aqueous layer was extracted with EtOAc $(3 \times$ $30 \mathrm{~mL}$ ) and the combined organic layers were washed with brine and dried over $\mathrm{MgSO}_{4}$. Filtration and evaporation afforded crude products, which were purified as indicated below.
General Method B: Synthesis of Thioacetic Derivatives 27 and 28. A solution of 4-phenyl-1H-imidazole-2-thiol or 4-(4-bromophenyl)- $1 \mathrm{H}$ imidazole-2-thiol (2.80 mmol) and $\mathrm{NaOH}(5.0 \mathrm{mmol})$ in EtOH $(5 \mathrm{~mL})$ was reflux for $1 \mathrm{~h}$. After cooling to rt, a solution of 2-chloroacetic acid $(2.80 \mathrm{mmol})$ in $\mathrm{EtOH}(2 \mathrm{~mL})$ was added. The reaction was stirred at reflux for an additional $3 \mathrm{~h}$ and then cooled to $0^{\circ} \mathrm{C}$. The reaction mixture was diluted with cold water $(5 \mathrm{~mL})$ and acidified with $1 \mathrm{M} \mathrm{HCl}$. The precipitated product was collected by filtration and washed with DCM $(2 \times 2 \mathrm{~mL})$.

General Method C: Synthesis of Compounds 31, 33, and 36-39. A mixture of acid $\mathbf{5 9}(0.20 \mathrm{mmol})$ and $\mathrm{SOCl}_{2}(2 \mathrm{~mL})$ was heated at $80^{\circ} \mathrm{C}$ for $2 \mathrm{~h}$. The solvent was removed under reduced pressure to give the acid chloride $\mathbf{6 0}$ as a white solid. The resulting solid was immediately dissolved in anhydrous DCM, and the resulting solution was added slowly dropwise at $0{ }^{\circ} \mathrm{C}$ to a solution of the corresponding substituted 2aminoimidazoles $(0.20 \mathrm{mmol})$ and TEA $(0.80 \mathrm{mmol})$ in anhydrous $\operatorname{DCM}(5 \mathrm{~mL})$. The reaction mixture was stirred at $40{ }^{\circ} \mathrm{C}$ for $36 \mathrm{~h}$ and then diluted with DCM $(20 \mathrm{~mL})$ and washed with saturated aqueous $\mathrm{NaHCO}_{3}$. The aqueous phase layer was then extracted with DCM $(2 \times$ $20 \mathrm{~mL}$ ), and the combined organic layers were dried over $\mathrm{MgSO}_{4}$ and filtered, and the solvent was removed under reduced pressure to afford a yellow oil, which was purified by flash chromatography, eluting with the solvent system specified.

General Method D: Synthesis of Amides 34-35. A mixture of acid $59(0.20 \mathrm{mmol})$ and $\mathrm{SOCl}_{2}(2 \mathrm{~mL})$ was heated at $80^{\circ} \mathrm{C}$ for $2 \mathrm{~h}$. The solvent was removed under reduced pressure to give $\mathbf{6 0}$ as a white solid. The resulting solid was immediately dissolved in anhydrous DCM, and the resulting solution was added slowly dropwise at $0{ }^{\circ} \mathrm{C}$ to a solution of the corresponding aniline $(0.20 \mathrm{mmol})$ and triethylamine $(0.80 \mathrm{mmol})$ in anhydrous DCM $(5 \mathrm{~mL})$. The reaction mixture was stirred at $\mathrm{rt}$ for $4 \mathrm{~h}$ and then diluted with DCM $(20 \mathrm{~mL})$ and washed with saturated aqueous $\mathrm{NaHCO}_{3}$. The aqueous phase layer was then extracted with DCM $(2 \times 20 \mathrm{~mL})$, and the combined organic layers were dried over $\mathrm{MgSO}_{4}$ and filtered, and the solvent was removed under reduced pressure to afford a yellow oil, which was purified by flash chromatography, eluting with the solvent system specified.

General Method E: Synthesis of $\alpha$-Chloroacetamides $40-43 . \mathrm{Et}_{3} \mathrm{~N}$ $(4.77 \mathrm{mmol})$ followed by a solution of chloroacetyl chloride $(4.77$ $\mathrm{mmol})$ in DCM $(3 \mathrm{~mL})$ were added to a stirred solution of the corresponding aniline $(4.38 \mathrm{mmol})$ in DCM $(5 \mathrm{~mL})$ at rt. The reaction mixture was stirred at $\mathrm{rt}$ for $2-4 \mathrm{~h}$. The reaction was then diluted with $\operatorname{DCM}(20 \mathrm{~mL})$ and washed with saturated aqueous $\mathrm{NaHCO}_{3}, 1 \mathrm{M} \mathrm{HCl}$, and brine and dried over anhydrous $\mathrm{MgSO}_{4}$, and the solvent was removed under reduced pressure. Compound $\mathbf{4 3}$ was purified by flash chromatography eluting with the solvent system specified, although other analogues were used in subsequent reactions without further purification. 
General Method F: Synthesis of Substituted N-(1H-Imidazol-2yl)acetamides 45-49. A mixture of the corresponding 2-bromoacetophenone derivative $(0.38 \mathrm{mmol})$ and acetylguanidine $(1.13 \mathrm{mmol})$ in anhydrous acetonitrile $(3 \mathrm{~mL})$ was heated at $100{ }^{\circ} \mathrm{C}$ using microwave irradiation for $15 \mathrm{~min}$. The solvent was removed, and the residue was taken in $\mathrm{H}_{2} \mathrm{O}(3 \mathrm{~mL})$ and filtered, and the solid was washed with $\mathrm{H}_{2} \mathrm{O}$ (2 $\mathrm{mL} \times 2)$ and $\mathrm{DCM}(2 \mathrm{~mL})$. The solid obtained was used in the next step without further purification.

General Method G: Synthesis of Substituted 2-Aminoimidazoles $50-54$. To a solution of the corresponding substituted $\mathrm{N}$ - $(1 \mathrm{H}$-imidazol2-yl)acetamides $(0.31 \mathrm{mmol})$ in a 1:1 v/v mixture of $\mathrm{MeOH}$ and $\mathrm{H}_{2} \mathrm{O}$ (2.4 mL) was added concentrated $\mathrm{H}_{2} \mathrm{SO}_{4}(0.6 \mathrm{~mL})$, and the reaction mixture was heated at $100{ }^{\circ} \mathrm{C}$ under microwave irradiation for $15-30$ $\min$. The reaction mixture was concentrated, and the resulting residue was resuspended in $\mathrm{H}_{2} \mathrm{O}(5 \mathrm{~mL})$, and a saturated aqueous $\mathrm{Na}_{2} \mathrm{CO}_{3}$ was added until $\mathrm{pH} 8$. The product was extracted into EtOAc $(3 \times 40 \mathrm{~mL})$. The combined organic fractions were dried over $\mathrm{MgSO}_{4}$, and the solvent was removed under reduced pressure. The resulting solid was used in the next reaction without further purification.

2-((4-(4-Bromophenyl)-1H-imidazol-2-yl)thio)- N-phenylacetamide (20). Compound $40(29 \mathrm{mg}, 0.17 \mathrm{mmol})$ was reacted with 4-(4bromophenyl)- $1 \mathrm{H}$-imidazole-2-thiol $(43 \mathrm{mg}, 0.17 \mathrm{mmol}$ ) according to general method A. Purification by flash chromatography $(1-20 \% \mathrm{v} / \mathrm{v}$ $\mathrm{MeOH}$ in DCM) afforded 20 (59 mg, $0.15 \mathrm{mmol}, 89 \%$ yield) as a white solid. ${ }^{1} \mathrm{H}$ NMR (400 MHz, MeOD) $\delta 7.62(\mathrm{br} \mathrm{s}, 2 \mathrm{H}), 7.56-7.39(\mathrm{~m}$, $5 \mathrm{H}), 7.36-7.17(\mathrm{~m}, 2 \mathrm{H}), 7.13-7.00(\mathrm{~m}, 1 \mathrm{H}), 3.82(\mathrm{~s}, 2 \mathrm{H}) \mathrm{ppm} .{ }^{13} \mathrm{C}$ NMR $(100 \mathrm{MHz}, \mathrm{MeOD}) \delta 169.6,141.3,139.6,132.8,129.8,129.8$, $127.5,125.5,121.4,121.2,121.2,116.7,39.6 \mathrm{ppm}$. LCMS (ESI-) $\mathrm{m} / z$ $388.0[\mathrm{M}-\mathrm{H}]^{-}$, retention time $2.20 \mathrm{~min}(100 \%)$. HRMS (ESI $): \mathrm{m} / z$ calculated for $\mathrm{C}_{17} \mathrm{H}_{15} \mathrm{BrN}_{3} \mathrm{OS}[\mathrm{M}+\mathrm{H}]^{+}: 388.0119$. Found: 388.0121 .

$\mathrm{N}$-(Benzofuran-5-yl)-2-((4-(4-bromophenyl)-1H-imidazol-2-yl)thio)acetamide (21). Compound $41(36 \mathrm{mg}, 0.17 \mathrm{mmol})$ was reacted with 4-(4-bromophenyl)-1H-imidazole-2-thiol (43 mg, $0.17 \mathrm{mmol}$ ) according to general method A. Purification by flash chromatography $(1-20 \% \mathrm{v} / \mathrm{v} \mathrm{MeOH}$ in DCM) afforded 21 (70 mg, $0.16 \mathrm{mmol}, 96 \%$ yield) as a white solid. ${ }^{1} \mathrm{H}$ NMR (400 MHz, DMSO- $\left.d_{6}\right) \delta 12.50$ (br s, $1 \mathrm{H}), 10.35$ (br s, $1 \mathrm{H}), 7.94(\mathrm{dd}, J=10.6,2.0 \mathrm{~Hz}, 2 \mathrm{H}), 7.73-7.64(\mathrm{~m}$, $2 \mathrm{H}), 7.52-7.44(\mathrm{~m}, 4 \mathrm{H}), 7.34(\mathrm{dd}, J=8.8,2.2 \mathrm{~Hz}, 1 \mathrm{H}), 6.91(\mathrm{dd}, J=2.2$, $1.0 \mathrm{~Hz}, 1 \mathrm{H}), 3.99(\mathrm{~s}, 2 \mathrm{H}) \mathrm{ppm} .{ }^{13} \mathrm{C}$ NMR $\left(100 \mathrm{MHz}, \mathrm{DMSO}-d_{6}\right) \delta$ $166.5,150.8,146.7,140.2,139.9,134.3,133.6,131.4,127.4,126.2,119.0$, $116.9,115.7,111.6,111.3,107.0,37.9$. LCMS (ESI-) $\mathrm{m} / z$ 428.0 [M $\mathrm{H}]^{-}$, retention time $2.22 \mathrm{~min}(100 \%)$. HRMS (ESI+): $\mathrm{m} / z$ calculated for $\mathrm{C}_{19} \mathrm{H}_{15} \mathrm{BrN}_{3} \mathrm{O}_{2} \mathrm{~S}[\mathrm{M}+\mathrm{H}]^{+}$: 428.0068. Found: 428.0065 .

2-((4-(4-Bromophenyl)-1H-imidazol-2-yl)thio)- $\mathrm{N}$-(4-iodophenyl)acetamide (22). Compound $42(50 \mathrm{mg}, 0.17 \mathrm{mmol})$ was reacted with 4(4-bromophenyl)-1H-imidazole-2-thiol (43 mg, $0.17 \mathrm{mmol}$ ) according to general method A. Purification by flash chromatography $(1-20 \% \mathrm{v} / \mathrm{v}$ $\mathrm{MeOH}$ in DCM) afforded $22(60 \mathrm{mg}, 0.11 \mathrm{mmol}, 69 \%$ yield $)$ as a white solid. ${ }^{1} \mathrm{H}$ NMR (500 MHz, MeOD) $\delta 7.63-7.58(\mathrm{~m}, 4 \mathrm{H}), 7.56-7.45$ $(\mathrm{m}, 3 \mathrm{H}), 7.38-7.31(\mathrm{~m}, 2 \mathrm{H}), 3.81(\mathrm{~s}, 2 \mathrm{H}) \mathrm{ppm}^{13} \mathrm{C}$ NMR $(125 \mathrm{MHz}$, MeOD) $\delta$ 169.6, 139.6, 138.9, 132.7, 127.5, 127.1, 123.0, 116.6, 111.4, 88.1, $39.7 \mathrm{ppm}$. LCMS (ESI-) $\mathrm{m} / z 511.7[\mathrm{M}-\mathrm{H}]^{-}$, retention time $2.30 \mathrm{~min}(100 \%)$. HRMS (ESI+): $m / z$ calculated for $\mathrm{C}_{17} \mathrm{H}_{14} \mathrm{BrIN}_{3} \mathrm{OS}$ $[\mathrm{M}+\mathrm{H}]^{+}:$513.9086. Found: 513.9087.

N-Phenyl-2-((4-phenyl-1H-imidazol-2-yl)thio)acetamide (23). Compound 40 (42 mg, $0.25 \mathrm{mmol})$ was reacted with 4-phenyl- $1 \mathrm{H}$ imidazole-2-thiol ( $44 \mathrm{mg}, 0.25 \mathrm{mmol}$ ) according to general method A. Purification by flash chromatography (1-20\% v/v MeOH in DCM) afforded 23 (61 mg, $0.20 \mathrm{mmol}, 82 \%$ yield) as a white solid. ${ }^{1} \mathrm{H}$ NMR $(500 \mathrm{MHz}, \mathrm{MeOD}) \delta 7.71(\mathrm{br} \mathrm{s}, 2 \mathrm{H}), 7.54-7.49(\mathrm{~m}, 2 \mathrm{H}), 7.47$ (br s, $1 \mathrm{H}), 7.35(\mathrm{t}, J=7.4 \mathrm{~Hz}, 2 \mathrm{H}), 7.31-7.20(\mathrm{~m}, 3 \mathrm{H}), 7.11-7.03(\mathrm{~m}, 1 \mathrm{H})$, $3.83(\mathrm{~s}, 2 \mathrm{H}) \mathrm{ppm} .{ }^{13} \mathrm{C}$ NMR $(125 \mathrm{MHz}, \mathrm{MeOD}) \delta 168.3,142.7,139.5$, 138.5, 138.2, 128.4, 128.3, 126.7, 124.4, 124.1, 123.7, 119.8, 38.3 ppm. LCMS (ESI-) $\mathrm{m} / z$ 308.0 $[\mathrm{M}-\mathrm{H}]^{-}$, retention time $1.82 \mathrm{~min}(95 \%)$. HRMS (ESI+): $m / z$ calculated for $\mathrm{C}_{17} \mathrm{H}_{16} \mathrm{~N}_{3} \mathrm{OS}[\mathrm{M}+\mathrm{H}]^{+}: 310.1014$. Found: 310.1004 .

$\mathrm{N}$-(Benzofuran-5-yl)-2-((4-phenyl-1H-imidazol-2-yl)thio)acetamide (24). Compound $41(36 \mathrm{mg}, 0.17 \mathrm{mmol})$ was reacted with 4phenyl- $1 \mathrm{H}$-imidazole-2-thiol $(30 \mathrm{mg}, 0.17 \mathrm{mmol})$ according to general method A. Purification by flash chromatography $(1-20 \% \mathrm{v} / \mathrm{v} \mathrm{MeOH}$ in
DCM) afforded 24 (42 mg, $0.12 \mathrm{mmol}, 70 \%$ yield) as a white solid. ${ }^{1} \mathrm{H}$ $\operatorname{NMR}(500 \mathrm{MHz}, \mathrm{MeOD}) \delta 7.87(\mathrm{~d}, J=2.1 \mathrm{~Hz}, 1 \mathrm{H}), 7.72(\mathrm{~d}, J=2.2 \mathrm{~Hz}$, $1 \mathrm{H}), 7.68(\mathrm{~d}, J=7.7 \mathrm{~Hz}, 2 \mathrm{H}), 7.46(\mathrm{br} \mathrm{s}, 1 \mathrm{H}), 7.40(\mathrm{~d}, J=8.8 \mathrm{~Hz}, 1 \mathrm{H})$, $7.37-7.29(\mathrm{~m}, 3 \mathrm{H}), 7.23(\mathrm{t}, J=7.4 \mathrm{~Hz}, 1 \mathrm{H}), 6.76(\mathrm{dd}, J=2.2,0.9 \mathrm{~Hz}$, $1 \mathrm{H}), 3.84(\mathrm{~s}, 2 \mathrm{H}) \mathrm{ppm} .{ }^{13} \mathrm{C}$ NMR (125 MHz, MeOD) $\delta 169.6,153.5$, 147.4, 140.9, 134.7, 129.8, 129.1, 128.1, 125.8, 118.9, 114.2, 112.1, 107.7, $39.7 \mathrm{ppm}$. LCMS (ESI-) $\mathrm{m} / z 348.0[\mathrm{M}-\mathrm{H}]^{-}$, retention time $1.81 \mathrm{~min}$ (100\%). HRMS (ESI+): $m / z$ calculated for $\mathrm{C}_{19} \mathrm{H}_{16} \mathrm{~N}_{3} \mathrm{O}_{2} \mathrm{~S}[\mathrm{M}+\mathrm{H}]^{+}$: 350.0963. Found: 350.0971.

$\mathrm{N}$-(4-lodophenyl)-2-((4-phenyl-1H-imidazol-2-yl)thio)acetamide (25). Compound $42(74 \mathrm{mg}, 0.25 \mathrm{mmol})$ was reacted with 4-phenyl- $1 \mathrm{H}$ imidazole-2-thiol ( $44 \mathrm{mg}, 0.25 \mathrm{mmol}$ ) according to general method A. Purification by flash chromatography $(1-20 \% \mathrm{v} / \mathrm{v} \mathrm{MeOH}$ in DCM) afforded 25 (70 mg, $0.16 \mathrm{mmol}, 70 \%$ yield) as a white solid. ${ }^{1} \mathrm{H}$ NMR $(500 \mathrm{MHz}, \mathrm{MeOD}) \delta 7.66(\mathrm{~d}, J=7.7 \mathrm{~Hz}, 2 \mathrm{H}), 7.61-7.54(\mathrm{~m}, 2 \mathrm{H}), 7.44$ (br s, 1H), 7.38-7.31 (m, 4H), $7.23(\mathrm{t}, J=6.7 \mathrm{~Hz}, 1 \mathrm{H}), 3.80(\mathrm{~s}, 2 \mathrm{H})$ ppm. ${ }^{13} \mathrm{C}$ NMR (125 MHz, MeOD) $\delta 169.7,140.8,139.6,138.9,129.8$, $128.2,125.8,123.0,88.1,39.8$ ppm. LCMS (ESI-) $\mathrm{m} / z$ 433.9 [M $\mathrm{H}]^{-}$, retention time $2.13 \mathrm{~min}$ (98\%). HRMS (ESI +$): \mathrm{m} / z$ calculated for $\mathrm{C}_{17} \mathrm{H}_{15} \mathrm{IN}_{3} \mathrm{OS}[\mathrm{M}+\mathrm{H}]^{+}:$435.9981. Found: 435.9989 .

$\mathrm{N}$-Isopropyl-2-((4-phenyl-1H-imidazol-2-yl)thio)acetamide (26). A solution of propan-2-amine $(22 \mu \mathrm{L}, 0.25 \mathrm{mmol}), 2-((4-p h e n y l-1 H$ imidazol-2-yl)thio)acetic acid (60 mg, $0.25 \mathrm{mmol})$, HATU (194 mg, $0.50 \mathrm{mmol})$, and DIPEA $(90 \mu \mathrm{L}, 0.50 \mathrm{mmol})$ in EtOAc $(10 \mathrm{~mL})$ was stirred for $5 \mathrm{~h}$ at $\mathrm{rt}$. The reaction mixture was diluted with EtOAc (40 $\mathrm{mL}$ ) and washed with saturated aqueous $\mathrm{NaHCO}_{3}(20 \mathrm{~mL})$, water $(20$ $\mathrm{mL})$, and brine $(20 \mathrm{~mL})$. The organic layer was dried over $\mathrm{MgSO}_{4}$ and filtered. The solvent was removed under reduced pressure to give an oil residue, which was purified by flash chromatography $(5-100 \% \mathrm{v} / \mathrm{v}$ EtOAc in petroleum ether) to give the desired product as a white solid $\left(50 \mathrm{mg}, 0.18 \mathrm{mmol}, 73 \%\right.$ yield). ${ }^{1} \mathrm{H}$ NMR (500 MHz, MeOD) $\delta 7.37$ (d, $J=7.8 \mathrm{~Hz}, 2 \mathrm{H}), 7.14(\mathrm{~s}, 1 \mathrm{H}), 7.05(\mathrm{t}, J=7.7 \mathrm{~Hz}, 2 \mathrm{H}), 6.93(\mathrm{t}, J=7.4 \mathrm{~Hz}$, $1 \mathrm{H}), 3.62(\mathrm{dt}, J=13.1,6.4 \mathrm{~Hz}, 1 \mathrm{H}), 3.00(\mathrm{~s}, 2 \mathrm{H}), 0.78(\mathrm{~d}, J=6.6 \mathrm{~Hz}, 6 \mathrm{H})$ ppm. ${ }^{13} \mathrm{C}$ NMR (125 MHz, MeOD) $\delta 170.3,141.1,140.8,133.7,129.7$, $128.1,125.7,119.7,43.0,38.8,22.4$ ppm. LCMS (ESI-) $\mathrm{m} / z$ 273.9 [M $-\mathrm{H}]^{-}$, retention time $1.52 \mathrm{~min}(100 \%)$. HRMS (ESI+): $m / z$ calculated for $\mathrm{C}_{14} \mathrm{H}_{18} \mathrm{~N}_{3} \mathrm{OS}[\mathrm{M}+\mathrm{H}]^{+}$: 276.1171. Found: 276.1172 .

2-((4-(4-Bromophenyl)-1H-imidazol-2-yl)thio)acetic Acid (27). Following general procedure $\mathrm{B}$, from 4-(4-bromophenyl)- $1 \mathrm{H}$-imidazole-2-thiol ( $250 \mathrm{mg}, 0.98 \mathrm{mmol})$ was obtained $27(220 \mathrm{mg}, 0.70 \mathrm{mmol}$, $72 \%$ yield) as a white solid. ${ }^{1} \mathrm{H}$ NMR $(400 \mathrm{MHz}, \mathrm{MeOD}) \delta 7.65-7.56$ (m, 2H), 7.57-7.39 (m, 3H), 3.80 (s, 2H) ppm. ${ }^{13} \mathrm{C}$ NMR (100 MHz, $\mathrm{MeOD}) \delta 172.9,141.9,140.2,132.9,132.6,127.5,121.8,118.9,37.4$ ppm. LCMS (ESI-) $\mathrm{m} / z 311.0[\mathrm{M}-\mathrm{H}]^{-}$, retention time $1.59 \mathrm{~min}$ (98\%). HRMS (ESI+): $m / z$ calculated for $\mathrm{C}_{11} \mathrm{H}_{10} \mathrm{BrN}_{2} \mathrm{O}_{2} \mathrm{~S}[\mathrm{M}+\mathrm{H}]^{+}$: 312.9646. Found: 312.9654.

2-((4-Phenyl-1H-imidazol-2-yl)thio)acetic Acid (28). Following general procedure $\mathrm{B}$, from 4-phenyl- $1 \mathrm{H}$-imidazole-2-thiol $(500 \mathrm{mg}$, $2.80 \mathrm{mmol}$ ) was obtained 28 (450 $\mathrm{mg}, 1.92 \mathrm{mmol}, 69 \%$ yield) as a white solid. ${ }^{1} \mathrm{H}$ NMR $(500 \mathrm{MHz}, \mathrm{MeOD}) \delta 7.68(\mathrm{~d}, J=7.2 \mathrm{~Hz}, 2 \mathrm{H}), 7.59$ (s, $1 \mathrm{H}), 7.41(\mathrm{t}, J=7.7 \mathrm{~Hz}, 2 \mathrm{H}), 7.32(\mathrm{t}, J=7.4 \mathrm{~Hz}, 1 \mathrm{H}), 3.86(\mathrm{~s}, 2 \mathrm{H}) \mathrm{ppm}$. ${ }^{13} \mathrm{C}$ NMR (125 MHz, MeOD) $\delta$ 172.7, 141.7, 139.6, 131.6, 130.0, 129.1, 126.0, 118.9, 37.5 ppm. LCMS (ESI+) $m / z 235.1[\mathrm{M}+\mathrm{H}]^{+}$, retention time $1.22 \mathrm{~min}(100 \%)$. HRMS (ESI + ): $m / z$ calculated for $\mathrm{C}_{11} \mathrm{H}_{11} \mathrm{~N}_{2} \mathrm{O}_{2} \mathrm{~S}$ $[\mathrm{M}+\mathrm{H}]^{+}: 235.0541$. Found: 235.0536

$\mathrm{N}$-(4-(1H-Imidazol-4-yl)phenyl)-2-((4-(4-bromophenyl)-1H-imidazol-2-yl)thio)acetamide (29). Compound $43(40 \mathrm{mg}, 0.17 \mathrm{mmol})$ was reacted with 4-(4-bromophenyl)-1H-imidazole-2-thiol (43 mg, 0.17 mmol) according to general method A. Purification by flash chromatography $(1-20 \% \mathrm{v} / \mathrm{v} \mathrm{MeOH}$ in DCM) afforded $29(51 \mathrm{mg}$, $0.12 \mathrm{mmol}, 69 \%$ yield) as a white solid. ${ }^{1} \mathrm{H}$ NMR $(400 \mathrm{MHz}, \mathrm{MeOD}) \delta$ $7.72(\mathrm{~d}, J=1.1 \mathrm{~Hz}, 1 \mathrm{H}), 7.66(\mathrm{~d}, J=8.5 \mathrm{~Hz}, 4 \mathrm{H}), 7.59-7.47(\mathrm{~m}, 5 \mathrm{H})$, 7.40 (br s, $1 \mathrm{H}), 3.86(\mathrm{~s}, 2 \mathrm{H}) \mathrm{ppm} .{ }^{13} \mathrm{C}$ NMR $(125 \mathrm{MHz}, \mathrm{MeOD}) \delta$ 169.4, 141.2, 138.4, 137.0, 132.8, 127.5, 126.2, 121.4, 116.7, 111.4, 39.7 ppm. LCMS (ESI-) $m / z 451.9[\mathrm{M}-\mathrm{H}]^{-}$, retention time $1.65 \mathrm{~min}$ (100\%). HRMS (ESI+): $m / z$ calculated for $\mathrm{C}_{20} \mathrm{H}_{17} \mathrm{BrN}_{5} \mathrm{OS}[\mathrm{M}+\mathrm{H}]^{+}$: 454.0337. Found: 454.0334 .

1-(4-(1H-Imidazol-4-yl)phenyl)-3-((5-(4-bromophenyl)-1H-imidazol-2-yl)methyl)urea (30). To a solution of 4-(1H-imidazol-4-yl)aniline $(50 \mathrm{mg}, 0.31 \mathrm{mmol})$ in THF $(5 \mathrm{~mL})$ was added 1,1-carbonyldiimidazole 
( $76 \mathrm{mg}, 0.47 \mathrm{mmol}$ ). The mixture was stirred at rt overnight, and then it was filtered. The filter was washed with THF $(2 \times 3 \mathrm{~mL})$ and the resulting solid $(30 \mathrm{mg}, 0.12 \mathrm{mmol})$ was dissolved in DMF $(3 \mathrm{~mL})$, and $44(42 \mathrm{mg}, 0.12 \mathrm{mmol})$ and $N, N$-diisopropylethylamine $(74 \mu \mathrm{L}, 0.48$ $\mathrm{mmol}$ ) were added. The reaction mixture was stirred at $\mathrm{rt}$ for $14 \mathrm{~h}$, and then it was poured into water, extracted with EtOAc, dried over $\mathrm{Na}_{2} \mathrm{SO}_{4}$, and concentrated. After cooling to $0{ }^{\circ} \mathrm{C}$, a $1: 5 \mathrm{v} / \mathrm{v}$ mixture of $\mathrm{MeOH}$ and DCM $(12 \mathrm{~mL})$ was added and the suspended solid was collected by filtration and dried at vacuum to yield 30 (35 $\mathrm{mg}, 0.08 \mathrm{mmol}, 26 \%$ yield) as a white solid. ${ }^{1} \mathrm{H}$ NMR $\left(500 \mathrm{MHz}, \mathrm{DMSO}-d_{6}\right) \delta 12.03(\mathrm{br} \mathrm{s}, 2 \mathrm{H}), 8.64$ (br s, $1 \mathrm{H}), 7.73-7.68(\mathrm{~m}, 2 \mathrm{H}), 7.64-7.59(\mathrm{~m}, 2 \mathrm{H}), 7.57(\mathrm{~d}, J=1.9 \mathrm{~Hz}$, $1 \mathrm{H}), 7.52-7.47(\mathrm{~m}, 2 \mathrm{H}), 7.47-7.39(\mathrm{~m}, 2 \mathrm{H}), 7.39-7.32(\mathrm{~m}, 2 \mathrm{H}), 6.58$ (br s, $1 \mathrm{H}), 4.33(\mathrm{~d}, J=5.5 \mathrm{~Hz}, 2 \mathrm{H}) \mathrm{ppm} .{ }^{13} \mathrm{C}$ NMR $(125 \mathrm{MHz}, \mathrm{DMSO}-$ $\left.d_{6}\right) \delta 155.5,146.9,140.6,138.9,138.9,135.9,134.6,131.7,128.8,126.6$, $125.1,125.0,119.0,118.4,118.2,113.7,111.7,37.6$ ppm. LCMS (ESI-) $\mathrm{m} / z 437.0[\mathrm{M}-\mathrm{H}]^{-}$, retention time $5.07 \mathrm{~min}(97 \%)$. HRMS (ESI+): $m / z$ calculated for $\mathrm{C}_{20} \mathrm{H}_{18} \mathrm{BrN}_{6} \mathrm{O}[\mathrm{M}+\mathrm{H}]^{+}:$437.0725. Found: 437.0725 .

$\mathrm{N}$-(4-(4-Bromophenyl)-1H-imidazol-2-yl)-2-(4-(1-methyl-1H-imidazol-4-yl)phenoxy)propanamide (31). 4-(4-Bromophenyl)- $1 \mathrm{H}$-imidazol-2-amine 50 ( $48 \mathrm{mg}, 0.20 \mathrm{mmol})$ was reacted with the acid chloride $60(53 \mathrm{mg}, 0.20 \mathrm{mmol})$ and $\mathrm{Et}_{3} \mathrm{~N}(112 \mu \mathrm{L}, 0.80 \mathrm{mmol})$ according to general method $\mathrm{C}$. The crude product was purified by flash chromatography $(0-20 \% \mathrm{v} / \mathrm{v} \mathrm{MeOH}$ in DCM) to give compound 31 as a white solid (64 mg, $0.14 \mathrm{mmol}, 67 \%$ yield). ${ }^{1} \mathrm{H}$ NMR (500 MHz, $\left.\mathrm{CDCl}_{3}\right) \delta 10.79(\mathrm{br} \mathrm{s}, 1 \mathrm{H}), 9.49(\mathrm{br} \mathrm{s}, 1 \mathrm{H}), 7.69(\mathrm{~d}, J=8.7 \mathrm{~Hz}, 2 \mathrm{H})$, $7.58-7.41(\mathrm{~m}, 5 \mathrm{H}), 7.18-6.97(\mathrm{~m}, 2 \mathrm{H}), 6.93(\mathrm{~d}, J=8.8 \mathrm{~Hz}, 2 \mathrm{H}), 4.86$ $(\mathrm{d}, J=6.8 \mathrm{~Hz}, 1 \mathrm{H}), 3.71(\mathrm{~s}, 3 \mathrm{H}), 1.65(\mathrm{~d}, J=6.7 \mathrm{~Hz}, 3 \mathrm{H}) \mathrm{ppm} .{ }^{13} \mathrm{C}$ NMR $\left(125 \mathrm{MHz}, \mathrm{CDCl}_{3}\right) \delta 171.5,155.2,141.8,141.2,138.0,137.2,131.7$, 129.1, 127.6, 126.3, 120.5, 115.8, 115.6, 115.3, 108.1, 74.6, 33.5, 18.5 $\mathrm{ppm}$. LCMS (ESI+) $\mathrm{m} / z 465.9[\mathrm{M}+\mathrm{H}]^{+}$, retention time $2.73 \mathrm{~min}$ (95\%). HRMS (ESI+): $m / z$ calculated for $\mathrm{C}_{22} \mathrm{H}_{21} \mathrm{BrN}_{5} \mathrm{O}_{2}[\mathrm{M}+\mathrm{H}]^{+}$: 466.0879. Found: 466.0874. ((S)-31): $69 \%$ yield. $[\alpha]_{\mathrm{D}}^{25}-40.2(c 1.0$, $\left.\mathrm{CHCl}_{3}\right)$. LCMS (ESI +$) \mathrm{m} / z 466.0[\mathrm{M}+\mathrm{H}]^{+}$, retention time $2.70 \mathrm{~min}$ (95\%). HRMS (ESI+): $m / z$ calculated for $\mathrm{C}_{22} \mathrm{H}_{21} \mathrm{BrN}_{5} \mathrm{O}_{2}[\mathrm{M}+\mathrm{H}]^{+}$: 466.0879. Found: 466.0879.

$\mathrm{N}$-(4-(1H-Imidazol-4-yl)phenyl)-2-((4-phenyl-1H-imidazol-2-yl)thio)acetamide (32). Compound $43(40 \mathrm{mg}, 0.17 \mathrm{mmol})$ was reacted with 4-(4-bromophenyl)-1 $\mathrm{H}$-imidazole-2-thiol $(30 \mathrm{mg}, 0.17 \mathrm{mmol})$ according to general method A. Purification by flash chromatography $(1-20 \% \mathrm{v} / \mathrm{v} \mathrm{MeOH}$ in DCM) afforded 32 (41 mg, $0.11 \mathrm{mmol}, 65 \%$ yield) as a white solid. ${ }^{1} \mathrm{H}$ NMR (400 MHz, DMSO- $\left.d_{6}\right) \delta 12.46$ (br s, $2 \mathrm{H}), 10.42(\mathrm{br} \mathrm{s}, 1 \mathrm{H}), 7.76(\mathrm{br} \mathrm{s}, 2 \mathrm{H}), 7.68(\mathrm{~d}, J=8.2 \mathrm{~Hz}, 4 \mathrm{H}), 7.56$ (d, $J$ $=8.5 \mathrm{~Hz}, 2 \mathrm{H}), 7.52(\mathrm{~s}, 1 \mathrm{H}), 7.34(\mathrm{br} \mathrm{s}, 2 \mathrm{H}), 7.19(\mathrm{br} \mathrm{s}, 1 \mathrm{H}), 3.99(\mathrm{~s}, 2 \mathrm{H})$ ppm. ${ }^{13} \mathrm{C}$ NMR $\left(125 \mathrm{MHz}\right.$, DMSO-d $\left.d_{6}\right) \delta 167.0,141.7,139.9,137.7$, $136.2,134.6,128.9,126.7,125.2,124.6,119.7,115.4,39.5$ ppm. LCMS (ESI+) $\mathrm{m} / z 376.1[\mathrm{M}+\mathrm{H}]^{+}$, retention time $0.88 \mathrm{~min}(100 \%)$. HRMS (ESI+): $m / z$ calculated for $\mathrm{C}_{20} \mathrm{H}_{18} \mathrm{~N}_{5} \mathrm{OS}[\mathrm{M}+\mathrm{H}]^{+}: 376.1232$. Found: 376.1241 .

$\mathrm{N}$-(4-(4-Bromophenyl)oxazol-2-yl)-2-(4-(1-methyl-1H-imidazol-4yl)phenoxy)propanamide (33). 4-(4-Bromophenyl)oxazol-2-amine 61 (39 mg, $0.16 \mathrm{mmol}$ ) was reacted with the acid chloride 60 (43 mg, 0.16 $\mathrm{mmol})$ and $\mathrm{Et}_{3} \mathrm{~N}(90 \mu \mathrm{L}, 0.64 \mathrm{mmol})$ according to general method C. The crude product was purified by flash chromatography $(0-15 \% \mathrm{v} / \mathrm{v}$ $\mathrm{MeOH}$ in DCM) to give compound 33 as a white solid (49 mg, 0.10 mmol, $64 \%$ yield). ${ }^{1} \mathrm{H}$ NMR (400 $\left.\mathrm{MHz}, \mathrm{CDCl}_{3}\right) \delta 9.13$ (br s, $\left.1 \mathrm{H}\right)$, 7.81-7.66 (m, 3H), 7.63-7.50 (m, 4H), $7.47(\mathrm{~s}, 1 \mathrm{H}), 7.13(\mathrm{~d}, J=1.3$ $\mathrm{Hz}, 1 \mathrm{H}), 7.03-6.94(\mathrm{~m}, 2 \mathrm{H}), 4.90(\mathrm{q}, J=6.6 \mathrm{~Hz}, 1 \mathrm{H}), 3.74(\mathrm{~s}, 3 \mathrm{H}), 1.70$ $(\mathrm{d}, J=6.8 \mathrm{~Hz}, 3 \mathrm{H}) \mathrm{ppm} .{ }^{13} \mathrm{C} \mathrm{NMR}\left(100 \mathrm{MHz}, \mathrm{CDCl}_{3}\right) \delta 155.1,141.7$, 138.0, 131.9, 131.7, 130.3, 129.4, 129.3, 127.8, 127.0, 126.7, 126.4, 122.2, 116.0, 115.4, 75.1, 33.5, 18.4 ppm. LCMS (ESI+) $\mathrm{m} / z 468.9[\mathrm{M}+\mathrm{H}]^{+}$, retention time $2.86 \mathrm{~min}(95 \%)$. HRMS (ESI+): $\mathrm{m} / z$ calculated for $\mathrm{C}_{22} \mathrm{H}_{20} \mathrm{BrN}_{4} \mathrm{O}_{3}[\mathrm{M}+\mathrm{H}]^{+}:$467.0719. Found: 467.0711.

2-(4-(1-Methyl-1H-imidazol-4-yl)phenoxy)-N-phenylpropanamide (34). Aniline $(28 \mu \mathrm{L}, 0.30 \mathrm{mmol})$ was reacted with the acid chloride $60(53 \mathrm{mg}, 0.20 \mathrm{mmol})$ and $\mathrm{Et}_{3} \mathrm{~N}(112 \mu \mathrm{L}, 0.80 \mathrm{mmol})$ according to general method $\mathrm{D}$. The crude product was purified by flash chromatography $(0-20 \% \mathrm{v} / \mathrm{v} \mathrm{MeOH}$ in DCM) to give compound 34 as a white solid (48 mg, $0.14 \mathrm{mmol}, 74 \%$ yield). ${ }^{1} \mathrm{H}$ NMR (400 MHz, $\left.\mathrm{CDCl}_{3}\right) \delta 8.25$ (br s, $\left.1 \mathrm{H}\right), 7.79-7.69(\mathrm{~m}, 2 \mathrm{H}), 7.60-7.52(\mathrm{~m}, 2 \mathrm{H}), 7.47$ $(\mathrm{d}, J=1.3 \mathrm{~Hz}, 1 \mathrm{H}), 7.35(\mathrm{dd}, J=8.5,7.3 \mathrm{~Hz}, 2 \mathrm{H}), 7.19-7.06(\mathrm{~m}, 2 \mathrm{H})$, $7.05-6.97(\mathrm{~m}, 2 \mathrm{H}), 4.82(\mathrm{q}, J=6.7 \mathrm{~Hz}, 1 \mathrm{H}), 3.73(\mathrm{~s}, 3 \mathrm{H}), 1.69(\mathrm{~d}, J=6.8$ $\mathrm{Hz}, 3 \mathrm{H}) \mathrm{ppm} .{ }^{13} \mathrm{C}$ NMR $\left(100 \mathrm{MHz}, \mathrm{CDCl}_{3}\right) \delta 170.3,155.6,141.8$, $137.9,137.0,129.0,129.0,126.3,124.7,120.0,116.0,115.3,75.6,33.5$, $18.7 \mathrm{ppm}$. LCMS (ESI+) $\mathrm{m} / z 322.2[\mathrm{M}+\mathrm{H}]^{+}$, retention time $1.86 \mathrm{~min}$ (97\%). HRMS (ESI+): $m / z$ calculated for $\mathrm{C}_{19} \mathrm{H}_{20} \mathrm{~N}_{3} \mathrm{O}_{2}[\mathrm{M}+\mathrm{H}]^{+}$: 322.1556. Found: 322.1552.

$\mathrm{N}$-(4-lodophenyl)-2-(4-(1-methyl-1H-imidazol-4-yl)phenoxy)propanamide (35). 4-Iodoaniline $(65 \mathrm{mg}, 0.30 \mathrm{mmol})$ was reacted with the acid chloride $60(53 \mathrm{mg}, 0.20 \mathrm{mmol})$ and $\mathrm{Et}_{3} \mathrm{~N}(112 \mu \mathrm{L}, 0.80 \mathrm{mmol})$ according to the general method $\mathrm{D}$. The crude product was purified by flash chromatography $(0-20 \% \mathrm{v} / \mathrm{v} \mathrm{MeOH}$ in DCM) to give compound 35 as a pink solid (62 mg, $0.14 \mathrm{mmol}, 68 \%$ yield). ${ }^{1} \mathrm{H}$ NMR $(400 \mathrm{MHz}$, $\left.\mathrm{CDCl}_{3}\right) \delta 8.28(\mathrm{br} \mathrm{s}, 1 \mathrm{H}), 7.77-7.69(\mathrm{~m}, 2 \mathrm{H}), 7.69-7.57(\mathrm{~m}, 2 \mathrm{H}), 7.47$ $(\mathrm{d}, J=1.4 \mathrm{~Hz}, 1 \mathrm{H}), 7.41-7.31(\mathrm{~m}, 2 \mathrm{H}), 7.11(\mathrm{~d}, J=1.3 \mathrm{~Hz}, 1 \mathrm{H}), 7.03-$ $6.91(\mathrm{~m}, 2 \mathrm{H}), 4.80(\mathrm{q}, J=6.7 \mathrm{~Hz}, 1 \mathrm{H}), 3.73(\mathrm{~s}, 3 \mathrm{H}), 1.67(\mathrm{~d}, J=6.8 \mathrm{~Hz}$, $3 \mathrm{H}) \mathrm{ppm} .{ }^{13} \mathrm{C}$ NMR $\left(100 \mathrm{MHz}, \mathrm{CDCl}_{3}\right) \delta 170.4,155.5,141.7,137.9$, 136.9, 129.0, 126.3, 126.0, 121.8, 116.0, 115.3, 87.9, 75.6, 33.5, 18.6 ppm. LCMS (ESI+) $m / z 448.2[\mathrm{M}+\mathrm{H}]^{+}$, retention time $2.47 \mathrm{~min}(96 \%)$. HRMS (ESI+): $m / z$ calculated for $\mathrm{C}_{19} \mathrm{H}_{19} \mathrm{IN}_{3} \mathrm{O}_{2}[\mathrm{M}+\mathrm{H}]^{+}: 448.0522$. Found: 448.0517.

2-(4-(1-Methyl-1H-imidazol-4-yl)phenoxy)-N-(4-phenyl-1H-imidazol-2-yl)propanamide (36). 4-Phenyl-1H-imidazol-2-amine 51 (33 $\mathrm{mg}, 0.20 \mathrm{mmol}$ ) was reacted with the acid chloride $60(53 \mathrm{mg}, 0.20$ $\mathrm{mmol})$ and $\mathrm{Et}_{3} \mathrm{~N}(112 \mu \mathrm{L}, 0.80 \mathrm{mmol})$ according to general method C. The crude product was purified by flash chromatography $(0-15 \% \mathrm{v} / \mathrm{v}$ $\mathrm{MeOH}$ in DCM) to give compound 36 as a brown solid ( $57 \mathrm{mg}, 0.15$ mmol, $72 \%$ yield). ${ }^{1} \mathrm{H} \mathrm{NMR}\left(400 \mathrm{MHz}, \mathrm{CDCl}_{3}\right) \delta 10.84$ (br s, $\left.1 \mathrm{H}\right), 9.51$ (br s, $1 \mathrm{H}), 7.78-7.56(\mathrm{~m}, 4 \mathrm{H}), 7.46(\mathrm{~d}, J=1.2 \mathrm{~Hz}, 1 \mathrm{H}), 7.39(\mathrm{t}, J=7.7$ $\mathrm{Hz}, 2 \mathrm{H}), 7.22-7.26(\mathrm{~m}, 1 \mathrm{H}), 7.14(\mathrm{~s}, 1 \mathrm{H}), 7.11(\mathrm{~d}, J=1.4 \mathrm{~Hz}, 1 \mathrm{H})$, $7.02-6.89(\mathrm{~m}, 2 \mathrm{H}), 4.89(\mathrm{q}, J=6.8 \mathrm{~Hz}, 1 \mathrm{H}), 3.73(\mathrm{~s}, 3 \mathrm{H}), 1.68(\mathrm{~d}, J=6.8$ $\mathrm{Hz}, 3 \mathrm{H})$ ppm. ${ }^{13} \mathrm{C} \mathrm{NMR}\left(125 \mathrm{MHz}, \mathrm{CDCl}_{3}\right) \delta 171.3,155.2,141.8$, 137.9, 129.1, 128.7, 126.9, 126.3, 124.6, 115.9, 115.3, 107.8, 74.5, 33.5, $18.5 \mathrm{ppm}$. LCMS (ESI+) $\mathrm{m} / z 388.1[\mathrm{M}+\mathrm{H}]^{+}$, retention time $4.44 \mathrm{~min}$ (100\%). HRMS (ESI+): $m / z$ calculated for $\mathrm{C}_{22} \mathrm{H}_{22} \mathrm{~N}_{5} \mathrm{O}_{2}[\mathrm{M}+\mathrm{H}]^{+}$: 388.1773. Found: 388.1767.

2-(4-(1-Methyl-1H-imidazol-4-yl)phenoxy)- $\mathrm{N}$-(4-(4-morpholinophenyl)-1H-imidazol-2-yl)propanamide (37). 4-(4-Morpholinophenyl)-1H-imidazol-2-amine $\mathbf{5 2}(40 \mathrm{mg}, 0.16 \mathrm{mmol})$ was reacted with the acid chloride $60(43 \mathrm{mg}, 0.16 \mathrm{mmol})$ and $\mathrm{Et}_{3} \mathrm{~N}(90 \mu \mathrm{L}, 0.65 \mathrm{mmol})$ according to general method $\mathrm{C}$. The crude product was purified by flash chromatography ( $3-15 \% \mathrm{v} / \mathrm{v} \mathrm{MeOH}$ in DCM) to give compound 37 as a brown solid (51 mg, $0.11 \mathrm{mmol}, 67 \%$ yield). ${ }^{1} \mathrm{H}$ NMR $(400 \mathrm{MHz}$, $\left.\mathrm{CDCl}_{3}\right) \delta 10.74(\mathrm{br} \mathrm{s}, 1 \mathrm{H}), 7.71(\mathrm{~d}, J=8.8 \mathrm{~Hz}, 2 \mathrm{H}), 7.54(\mathrm{br} \mathrm{s}, 2 \mathrm{H}), 7.47$ $(\mathrm{d}, J=1.4 \mathrm{~Hz}, 1 \mathrm{H}), 7.11(\mathrm{~d}, J=1.4 \mathrm{~Hz}, 1 \mathrm{H}), 7.03-6.88(\mathrm{~m}, 5 \mathrm{H}), 4.90(\mathrm{q}$, $J=6.7 \mathrm{~Hz}, 1 \mathrm{H}), 4.06-3.83(\mathrm{~m}, 4 \mathrm{H}), 3.73(\mathrm{~s}, 3 \mathrm{H}), 3.27-3.01(\mathrm{~m}, 4 \mathrm{H})$, $1.69(\mathrm{~d}, J=6.8 \mathrm{~Hz}, 3 \mathrm{H}) \mathrm{ppm} .{ }^{13} \mathrm{C} \mathrm{NMR}\left(125 \mathrm{MHz}, \mathrm{CDCl}_{3}\right) \delta 171.5$, $155.3,150.3,141.8,141.0,137.9,137.8,128.9,126.3,125.5,115.8,115.3$, 74.4, 66.9, 49.3, 33.6, 18.7 ppm. LCMS (ESI+) $m / z 473.2[\mathrm{M}+\mathrm{H}]^{+}$, retention time $2.22 \mathrm{~min}(100 \%)$. HRMS (ESI+): $\mathrm{m} / z$ calculated for $\mathrm{C}_{26} \mathrm{H}_{29} \mathrm{~N}_{6} \mathrm{O}_{3}[\mathrm{M}+\mathrm{H}]^{+}$: 473.2301. Found: 473.2297.

$\mathrm{N}$-(4-(4-Methoxyphenyl)-1H-imidazol-2-yl)-2-(4-(1-methyl-1Himidazol-4-yl)phenoxy)propanamide (38). 4-(4-Methoxyphenyl)$1 \mathrm{H}$-imidazol-2-amine $53(30 \mathrm{mg}, 0.16 \mathrm{mmol})$ was reacted with the acid chloride $60(43 \mathrm{mg}, 0.16 \mathrm{mmol})$ and $\mathrm{Et}_{3} \mathrm{~N}(90 \mu \mathrm{L}, 0.65 \mathrm{mmol})$ according to general method $\mathrm{C}$. The crude product was purified by flash chromatography $(1-20 \% \mathrm{v} / \mathrm{v} \mathrm{MeOH}$ in DCM $)$ to give compound 38 as a yellow solid (45 mg, $0.11 \mathrm{mmol}, 67 \%$ yield). ${ }^{1} \mathrm{H}$ NMR (400 MHz, $\left.\mathrm{CDCl}_{3}\right) \delta 10.73(\mathrm{br} \mathrm{s}, 1 \mathrm{H}), 9.62(\mathrm{br} \mathrm{s}, 1 \mathrm{H}), 7.78-7.65(\mathrm{~m}, 2 \mathrm{H}), 7.57(\mathrm{br}$ s, $2 \mathrm{H}), 7.46(\mathrm{~d}, J=1.4 \mathrm{~Hz}, 1 \mathrm{H}), 7.10(\mathrm{~d}, J=1.3 \mathrm{~Hz}, 1 \mathrm{H}), 7.02(\mathrm{~s}, 1 \mathrm{H})$, $6.95(\mathrm{dd}, J=10.5,8.8 \mathrm{~Hz}, 4 \mathrm{H}), 4.88(\mathrm{q}, J=6.8 \mathrm{~Hz}, 1 \mathrm{H}), 3.84(\mathrm{~s}, 3 \mathrm{H})$, $3.73(\mathrm{~s}, 3 \mathrm{H}), 1.68(\mathrm{~d}, J=6.8 \mathrm{~Hz}, 3 \mathrm{H}) \mathrm{ppm} .{ }^{13} \mathrm{C}$ NMR $(125 \mathrm{MHz}$, $\left.\mathrm{CDCl}_{3}\right) \delta 171.4,158.7,155.3,141.8,140.8,137.9,129.1,126.3,125.8$, $115.8,115.3,114.2,74.7,55.3,33.4,18.4$ ppm. LCMS (ESI+) $\mathrm{m} / z 418.3$ $[\mathrm{M}+\mathrm{H}]^{+}$, retention time $4.69 \mathrm{~min}(100 \%)$. HRMS (ESI+): $\mathrm{m} / \mathrm{z}$ calculated for $\mathrm{C}_{23} \mathrm{H}_{24} \mathrm{~N}_{5} \mathrm{O}_{3}[\mathrm{M}+\mathrm{H}]^{+}:$: 18.1879 . Found: 418.1875 .

$\mathrm{N}$-(4-(4-Iodophenyl)-1H-imidazol-2-yl)-2-(4-(1-methyl-1H-imidazol-4-yl)phenoxy)propanamide (39). 4-(4-Iodophenyl)-1H-imidazol2-amine $54(46 \mathrm{mg}, 0.16 \mathrm{mmol})$ was reacted with the acid chloride $\mathbf{6 0}$ (43 mg, $0.16 \mathrm{mmol})$ and $\mathrm{Et}_{3} \mathrm{~N}(90 \mu \mathrm{L}, 0.65 \mathrm{mmol})$ according to general 
method C. The crude product was purified by flash chromatography $(1-20 \% \mathrm{v} / \mathrm{v} \mathrm{MeOH}$ in DCM) to give compound 39 as a yellow solid (50 mg, $0.10 \mathrm{mmol}, 61 \%$ yield). ${ }^{1} \mathrm{H}$ NMR $\left(500 \mathrm{MHz}, \mathrm{CDCl}_{3}\right) \delta 10.75$ (br s, $1 \mathrm{H}), 9.42(\mathrm{br} \mathrm{s}, 1 \mathrm{H}), 7.69(\mathrm{t}, J=8.3 \mathrm{~Hz}, 4 \mathrm{H}), 7.53-7.33(\mathrm{~m}, 3 \mathrm{H})$, $7.10(\mathrm{~d}, J=8.3 \mathrm{~Hz}, 2 \mathrm{H}), 6.95(\mathrm{~d}, J=8.9 \mathrm{~Hz}, 2 \mathrm{H}), 4.88(\mathrm{q}, J=6.7 \mathrm{~Hz}$, $1 \mathrm{H}), 3.71(\mathrm{~s}, 3 \mathrm{H}), 1.66(\mathrm{~d}, J=6.7 \mathrm{~Hz}, 3 \mathrm{H}) \mathrm{ppm} .{ }^{13} \mathrm{C} \mathrm{NMR}(125 \mathrm{MHz}$, $\left.\mathrm{CDCl}_{3}\right) \delta 171.5,155.2,141.7,138.0,137.7,129.1,126.5,126.3,115.8$, $115.3,108.1,91.8,74.5,33.5,18.5 \mathrm{ppm}$. LCMS (ESI+) $\mathrm{m} / z 514.2[\mathrm{M}+$ $\mathrm{H}^{+}$, retention time $4.61 \mathrm{~min}(95 \%)$. HRMS (ESI +$): \mathrm{m} / z$ calculated for $\mathrm{C}_{22} \mathrm{H}_{21} \mathrm{IN}_{5} \mathrm{O}_{2}[\mathrm{M}+\mathrm{H}]^{+}:$514.0740. Found: 514.0740.

2-Chloro-N-phenylacetamide (40). Aniline (400 $\mu \mathrm{L}, 4.38 \mathrm{mmol})$ was reacted with chloroacetyl chloride $(380 \mu \mathrm{L}, 4.77 \mathrm{mmol})$ and $\mathrm{Et}_{3} \mathrm{~N}$ (670 $\mu \mathrm{L}, 4.77 \mathrm{mmol}$ ) according to general method $\mathrm{E}$, and used in subsequent reactions without further purification. Compound $\mathbf{4 0}$ was obtained (720 mg, $4.24 \mathrm{mmol}, 96 \%$ yield) as a green solid and was used without further purification. ${ }^{1} \mathrm{H}$ NMR $\left(400 \mathrm{MHz}, \mathrm{CDCl}_{3}\right) \delta 8.27$ (br s, $1 \mathrm{H}), 7.58(\mathrm{~d}, J=7.7 \mathrm{~Hz}, 2 \mathrm{H}), 7.39(\mathrm{t}, J=7.9 \mathrm{~Hz}, 2 \mathrm{H}), 7.20(\mathrm{t}, J=7.4 \mathrm{~Hz}$, $1 \mathrm{H}), 4.22(\mathrm{~s}, 2 \mathrm{H}) \mathrm{ppm} .{ }^{13} \mathrm{C} \mathrm{NMR}\left(100 \mathrm{MHz}, \mathrm{CDCl}_{3}\right) \delta 163.9,136.8$, 129.3, 125.4, 120.2, 43.0 ppm. LCMS (ESI+) $m / z 170.1[\mathrm{M}+\mathrm{H}]^{+}$, retention time $1.58 \mathrm{~min}(100 \%)$. HRMS (ESI $): \mathrm{m} / z$ calculated for $\mathrm{C}_{8} \mathrm{H}_{9} \mathrm{ClNO}[\mathrm{M}+\mathrm{H}]^{+}:$170.0373. Found: 170.0366 . NMR data is in accordance with literature values. ${ }^{39}$

$\mathrm{N}$-(Benzofuran-5-yl)-2-chloroacetamide (41). Benzofuran-5-amine $(140 \mathrm{mg}, 1.05 \mathrm{mmol})$ was reacted with chloroacetyl chloride $(93 \mu \mathrm{L}$, $1.16 \mathrm{mmol})$ and $\mathrm{Et}_{3} \mathrm{~N}(162 \mu \mathrm{L}, 1.16 \mathrm{mmol})$ according to general method E, and it was used in subsequent reactions without further purification. Compound 41 was obtained $(219 \mathrm{mg}, 1.04 \mathrm{mmol}, 99 \%$ yield) as a green solid and was used without further purification. ${ }^{1} \mathrm{H}$ NMR $\left(400 \mathrm{MHz}, \mathrm{CDCl}_{3}\right) \delta 8.41($ br s, $1 \mathrm{H}), 7.94(\mathrm{~d}, J=2.2 \mathrm{~Hz}, 1 \mathrm{H})$, $7.64(\mathrm{~d}, J=2.2 \mathrm{~Hz}, 1 \mathrm{H}), 7.47(\mathrm{dd}, J=8.8,0.8 \mathrm{~Hz}, 1 \mathrm{H}), 7.32(\mathrm{dd}, J=8.8$, $2.2 \mathrm{~Hz}, 1 \mathrm{H}), 6.76(\mathrm{dd}, J=2.2,0.9 \mathrm{~Hz}, 1 \mathrm{H}), 4.23(\mathrm{~s}, 2 \mathrm{H}) \mathrm{ppm} .{ }^{13} \mathrm{C} \mathrm{NMR}$ $\left(100 \mathrm{MHz}, \mathrm{CDCl}_{3}\right) \delta 163.9,152.4,146.1,131.9,127.9,117.7,113.3$, 111.6, 106.8, $43.0 \mathrm{ppm}$. LCMS (ESI+) $\mathrm{m} / z 210.1[\mathrm{M}+\mathrm{H}]^{+}$, retention time $1.71 \mathrm{~min}(100 \%)$. HRMS (ESI+): $m / z$ calculated for $\mathrm{C}_{11} \mathrm{H}_{9} \mathrm{ClNO}_{2}$ $[\mathrm{M}+\mathrm{H}]^{+}: 210.0322$. Found: 210.0319 .

2-Chloro-N-(4-iodophenyl)acetamide (42). 4-Iodoaniline (500 mg, $2.28 \mathrm{mmol})$ was reacted with chloroacetyl chloride $(200 \mu \mathrm{L}, 2.51 \mathrm{mmol})$ and $\mathrm{Et}_{3} \mathrm{~N}(350 \mu \mathrm{L}, 2.51 \mathrm{mmol})$ according to general method $\mathrm{E}$. The crude product was purified by flash chromatography $(10-100 \% \mathrm{v} / \mathrm{v}$ EtOAc in petroleum ether) to give compound $\mathbf{4 2}$ as a brown solid (600 $\mathrm{mg}, 2.03 \mathrm{mmol}, 89 \%$ yield). ${ }^{1} \mathrm{H}$ NMR $\left(400 \mathrm{MHz}, \mathrm{CDCl}_{3}\right) \delta 8.32-8.11$ (br s, $1 \mathrm{H}), 7.69(\mathrm{~d}, J=8.8 \mathrm{~Hz}, 2 \mathrm{H}), 7.36(\mathrm{~d}, J=8.7 \mathrm{~Hz}, 2 \mathrm{H}), 4.20(\mathrm{~s}, 2 \mathrm{H})$ ppm. ${ }^{13} \mathrm{C} \mathrm{NMR}\left(100 \mathrm{MHz}, \mathrm{CDCl}_{3}\right) \delta 163.8,138.1,136.4,121.8,88.7$, $42.9 \mathrm{ppm}$. LCMS (ESI-) $\mathrm{m} / \mathrm{z} 293.7[\mathrm{M}-\mathrm{H}]^{-}$, retention time $2.38 \mathrm{~min}$ (100\%). HRMS (ESI-): $m / z$ calculated for $\mathrm{C}_{8} \mathrm{H}_{6} \mathrm{ClINO}[\mathrm{M}-\mathrm{H}]^{-}$: 293.9183. Found: 293.9187 . NMR data is in accordance with literature values. ${ }^{40}$

$\mathrm{N}$-(4-(1H-Imidazol-4-yl)phenyl)-2-chloroacetamide (43). 4-(1HImidazol-4-yl)aniline $(200 \mathrm{mg}, 1.25 \mathrm{mmol})$ was reacted with chloroacetyl chloride $(109 \mu \mathrm{L}, 1.38 \mathrm{mmol})$ and $\mathrm{Et}_{3} \mathrm{~N}(192 \mu \mathrm{L}, 1.38$ $\mathrm{mmol}$ ) according to general method $\mathrm{E}$. The crude product was purified by flash chromatography $(3-20 \% \mathrm{v} / \mathrm{v} \mathrm{MeOH}$ in $\mathrm{DCM})$ to give compound 43 as a yellow solid $(264 \mathrm{mg}, 1.12 \mathrm{mmol}, 89 \%$ yield $) .{ }^{1} \mathrm{H}$ NMR (400 MHz, DMSO- $\left.d_{6}\right) \delta 10.43($ br s, $1 \mathrm{H}), 9.83$ (br s, $\left.1 \mathrm{H}\right), 7.98$ (br s, $1 \mathrm{H}), 7.77-7.65(\mathrm{~m}, 2 \mathrm{H}), 7.70-7.47(\mathrm{~m}, 3 \mathrm{H}), 4.27(\mathrm{~s}, 2 \mathrm{H}) \mathrm{ppm}$. LCMS (ESI+) $m / z 236.2[\mathrm{M}+\mathrm{H}]^{+}$, retention time $1.15 \mathrm{~min}(100 \%)$. HRMS (ESI+): $m / z$ calculated for $\mathrm{C}_{11} \mathrm{H}_{10} \mathrm{ClN}_{3} \mathrm{O}[\mathrm{M}+\mathrm{H}]^{+}: 236.0591$. Found: 236.0590 .

(5-(4-Bromophenyl)-1H-imidazol-2-yl)methanamine Hydrochloride (44). $4 \mathrm{M} \mathrm{HCl}(2 \mathrm{~mL})$ was added slowly to a stirred solution of benzyl ((5-(4-bromophenyl)-1H-imidazol-2-yl)methyl) carbamate $^{36}$ $(105 \mathrm{mg}, 0.26 \mathrm{mmol})$ in dioxane $(1 \mathrm{~mL})$. The mixture was stirred at $100{ }^{\circ} \mathrm{C}$ for $4 \mathrm{~h}$, and then the solvents were removed under reduced pressure to give the desired product as a white solid $(86 \mathrm{mg}, 0.26 \mathrm{mmol}$, $100 \%$ yield). ${ }^{1} \mathrm{H}$ NMR $(500 \mathrm{MHz}, \mathrm{MeOD}) \delta 8.00(\mathrm{~s}, 1 \mathrm{H}), 7.75-7.67$ $(\mathrm{m}, 4 \mathrm{H}), 4.55$ (s, 2H) ppm. ${ }^{13} \mathrm{C}$ NMR (125 MHz, MeOD) $\delta 140.8$, 136.0, 133.7, 128.4, 127.6, 124.7, 117.8, 111.4, 34.8 ppm. LCMS (ESI-) $\mathrm{m} / z 250.1[\mathrm{M}-\mathrm{H}]^{-}$, retention time $2.13 \mathrm{~min}(100 \%)$. HRMS (ESI-): $m / z$ calculated for $\mathrm{C}_{10} \mathrm{H}_{9} \mathrm{BrN}_{3}[\mathrm{M}+\mathrm{H}]^{+}:$249.9980. Found: 249.9987 .
$\mathrm{N}$-(4-(4-Bromophenyl)-1H-imidazol-2-yl)acetamide (45). Following general method $\mathrm{F}$, from 2-bromo-1-(4-bromophenyl)ethanone (104 $\mathrm{mg}, 0.38 \mathrm{mmol})$ was obtained $45(88 \mathrm{mg}, 0.31 \mathrm{mmol}, 84 \%$ yield $)$ as a green solid. ${ }^{1} \mathrm{H}$ NMR ( $\left.500 \mathrm{MHz}, \mathrm{DMSO}-d_{6}\right) \delta 11.66$ (br s, 1H), 11.20 (br s, $1 \mathrm{H}), 7.72-7.57(\mathrm{~m}, 2 \mathrm{H}), 7.54-7.42(\mathrm{~m}, 2 \mathrm{H}), 7.30(\mathrm{~d}, J=1.6 \mathrm{~Hz}$, $1 \mathrm{H}), 2.05(\mathrm{~s}, 3 \mathrm{H}) \mathrm{ppm} .{ }^{13} \mathrm{C}$ NMR $\left(125 \mathrm{MHz}\right.$, DMSO- $\left.d_{6}\right) \delta 169.0,141.9$, $135.5,134.4,131.7,126.4,119.0,110.4,23.3 \mathrm{ppm}$. LCMS (ESI+) $\mathrm{m} / \mathrm{z}$ $282.1[\mathrm{M}+\mathrm{H}]^{+}$, retention time $2.13 \mathrm{~min}(100 \%)$. HRMS (ESI+): $\mathrm{m} / z$ calculated for $\mathrm{C}_{11} \mathrm{H}_{11} \mathrm{BrN}_{3} \mathrm{O}[\mathrm{M}+\mathrm{H}]^{+}:$280.0085. Found: 280.0080 . NMR data is in accordance with literature values. ${ }^{37}$

$\mathrm{N}$-(4-Phenyl-1H-imidazol-2-yl)acetamide (46). Following general method F, from 2-bromo-1-phenylethan-1-one $(100 \mathrm{mg}, 0.50 \mathrm{mmol})$ was obtained 46 (79 mg, $0.39 \mathrm{mmol}, 78 \%$ yield) as a green solid. ${ }^{1} \mathrm{H}$ NMR (400 MHz, DMSO- $\left.d_{6}\right) \delta 11.59$ (br s, $\left.1 \mathrm{H}\right), 11.24$ (br s, $\left.1 \mathrm{H}\right), 7.71$ $(\mathrm{d}, J=7.6 \mathrm{~Hz}, 2 \mathrm{H}), 7.32(\mathrm{t}, J=7.6 \mathrm{~Hz}, 2 \mathrm{H}), 7.25(\mathrm{br} \mathrm{s}, 1 \mathrm{H}), 7.16(\mathrm{t}, J=$ $7.4 \mathrm{~Hz}, 1 \mathrm{H}), 2.07$ (s, $3 \mathrm{H}) \mathrm{ppm} .{ }^{13} \mathrm{C}$ NMR $\left(100 \mathrm{MHz}, \mathrm{DMSO}-d_{6}\right) \delta$ $169.0,141.7,136.6,128.9,126.3,124.4,109.6,23.3$ ppm. LCMS (ESI-) $\mathrm{m} / z 200.0[\mathrm{M}-\mathrm{H}]^{-}$, retention time $1.44 \mathrm{~min}(100 \%)$. HRMS (ESI+): $m / z$ calculated for $\mathrm{C}_{11} \mathrm{H}_{12} \mathrm{~N}_{3} \mathrm{O}[\mathrm{M}+\mathrm{H}]^{+}: 202.0980$. Found: 202.0977 . NMR data is in accordance with literature values. ${ }^{37}$

$\mathrm{N}$-(4-(4-Morpholinophenyl)-1H-imidazol-2-yl)acetamide (47). Following general method F, from 2-bromo-1-(4-(piperidin-1-yl)phenyl)ethan-1-one (106 mg, $0.38 \mathrm{mmol})$ was obtained 47 (90 mg, $0.31 \mathrm{mmol}, 83 \%$ yield $)$ as a brown solid. ${ }^{1} \mathrm{H}$ NMR (500 MHz, DMSO$\left.d_{6}\right) \delta 11.46(\mathrm{br} \mathrm{s}, 1 \mathrm{H}), 11.17(\mathrm{br} \mathrm{s}, 1 \mathrm{H}), 7.55(\mathrm{~d}, J=8.2 \mathrm{~Hz}, 2 \mathrm{H}), 7.06(\mathrm{br}$ $\mathrm{s}, 1 \mathrm{H}), 6.89(\mathrm{~d}, J=8.5 \mathrm{~Hz}, 2 \mathrm{H}), 3.93-3.53(\mathrm{~m}, 4 \mathrm{H}), 3.07(\mathrm{t}, J=4.8 \mathrm{~Hz}$, $4 \mathrm{H}), 2.04(\mathrm{~s}, 3 \mathrm{H}) \mathrm{ppm} .{ }^{13} \mathrm{C}$ NMR $(125 \mathrm{MHz}$, DMSO-d 6 ) $\delta 168.8,149.8$, 141.4, 136.8, 125.2, 115.6, 113.5, 107.9, 66.6, 49.0, 23.2 ppm. LCMS (ESI-) $\mathrm{m} / z 285.1[\mathrm{M}-\mathrm{H}]^{-}$, retention time $1.60 \mathrm{~min}$ (95\%). HRMS (ESI+): $m / z$ calculated for $\mathrm{C}_{15} \mathrm{H}_{19} \mathrm{~N}_{4} \mathrm{O}_{2}[\mathrm{M}+\mathrm{H}]^{+}: 287.1508$. Found: 287.1505.

$\mathrm{N}$-(4-(4-Methoxyphenyl)-1H-imidazol-2-yl)acetamide (48). Following general method $\mathrm{F}$, from 2-bromo-1-(4-methoxyphenyl)ethan1-one (150 mg, $0.66 \mathrm{mmol})$ was obtained $48(110 \mathrm{mg}, 0.47 \mathrm{mmol}, 71 \%$ yield) as a white solid. ${ }^{1} \mathrm{H}$ NMR $\left(400 \mathrm{MHz}, \mathrm{DMSO}-d_{6}\right) \delta 11.52$ (br s, $1 \mathrm{H}), 11.20(\mathrm{br} \mathrm{s}, 1 \mathrm{H}), 7.62(\mathrm{~d}, J=8.1 \mathrm{~Hz}, 2 \mathrm{H}), 7.11(\mathrm{~s}, 1 \mathrm{H}), 6.89(\mathrm{~d}, J=$ $8.4 \mathrm{~Hz}, 2 \mathrm{H}), 3.75(\mathrm{~s}, 3 \mathrm{H}), 2.06(\mathrm{~s}, 3 \mathrm{H}) \mathrm{ppm} .{ }^{13} \mathrm{C}$ NMR $(100 \mathrm{MHz}$, DMSO- $\left.d_{6}\right) \delta 168.5,157.8,141.2,136.1,127.6,125.3,113.9,107.9,55.1$, $22.9 \mathrm{ppm}$. LCMS (ESI-) $\mathrm{m} / z 230.1[\mathrm{M}-\mathrm{H}]^{-}$, retention time $1.52 \mathrm{~min}$ (96\%). HRMS (ESI+): $m / z$ calculated for $\mathrm{C}_{12} \mathrm{H}_{14} \mathrm{~N}_{3} \mathrm{O}_{2}[\mathrm{M}+\mathrm{H}]^{+}$: 232.1086. Found: 232.1082 . NMR data is in accordance with literature values. $^{37}$

$\mathrm{N}$-(4-(4-lodophenyl)-1H-imidazol-2-yl)acetamide (49). Following general method F, from 2-bromo-1-(4-iodophenyl)ethan-1-one (214 $\mathrm{mg}, 0.66 \mathrm{mmol})$ was obtained $49(190 \mathrm{mg}, 0.58 \mathrm{mmol}, 88 \%$ yield $)$ as a green solid. ${ }^{1} \mathrm{H}$ NMR $\left(500 \mathrm{MHz}, \mathrm{DMSO}-d_{6}\right) \delta 11.66(\mathrm{br} \mathrm{s}, 1 \mathrm{H}), 11.21$ (br s, $1 \mathrm{H}), 7.64(\mathrm{~d}, J=8.1 \mathrm{~Hz}, 2 \mathrm{H}), 7.51(\mathrm{~d}, J=8.1 \mathrm{~Hz}, 2 \mathrm{H}), 7.30(\mathrm{~s}, 1 \mathrm{H})$, $2.05(\mathrm{~s}, 3 \mathrm{H}) \mathrm{ppm} .{ }^{13} \mathrm{C}$ NMR $\left(125 \mathrm{MHz}\right.$, DMSO- $\left.d_{6}\right) \delta 168.5,141.4$, 137.1, 135.1, 134.3, 126.2, 109.9, 90.9, 22.8. LCMS (ESI-) $m / z 326.0$ $[\mathrm{M}-\mathrm{H}]^{-}$, retention time $2.43 \mathrm{~min}(100 \%)$. HRMS (ESI+): $\mathrm{m} / \mathrm{z}$ calculated for $\mathrm{C}_{11} \mathrm{H}_{11} \mathrm{IN}_{3} \mathrm{O}[\mathrm{M}+\mathrm{H}]^{+}: 327.9947$. Found: 327.9945 .

4-(4-Bromophenyl)-1H-imidazol-2-amine (50). Following general method G, from $\mathrm{N}$-(4-(4-bromophenyl)-1H-imidazol-2-yl)acetamide 45 ( $88 \mathrm{mg}, 0.31 \mathrm{mmol})$ was obtained $50(70 \mathrm{mg}, 0.29 \mathrm{mmol}, 95 \%$ yield $)$ as a brown solid. ${ }^{1} \mathrm{H}$ NMR $\left(500 \mathrm{MHz}, \mathrm{DMSO}-d_{6}\right) \delta 7.52(\mathrm{~d}, J=8.1 \mathrm{~Hz}$ $2 \mathrm{H}), 7.42(\mathrm{~d}, J=8.6 \mathrm{~Hz}, 2 \mathrm{H}), 7.04(\mathrm{~s}, 1 \mathrm{H}), 5.40(\mathrm{br} \mathrm{s}, 2 \mathrm{H}) \mathrm{ppm} .{ }^{13} \mathrm{C}$ NMR $\left(125 \mathrm{MHz}\right.$, DMSO- $\left.d_{6}\right) \delta 150.4,134.0,131.2,126.0,125.4,117.5$, $110.5 \mathrm{ppm}$. LCMS (ESI+) $\mathrm{m} / z 240.1[\mathrm{M}+\mathrm{H}]^{+}$, retention time $1.50 \mathrm{~min}$ (97\%). HRMS (ESI+): $m / z$ calculated for $\mathrm{C}_{9} \mathrm{H}_{9} \mathrm{BrN}_{3}[\mathrm{M}+\mathrm{H}]^{+}$: 237.9980. Found: 237.9980 . NMR data is in accordance with literature values.

4-Phenyl-1H-imidazol-2-amine (51). Following general method G, from $\mathrm{N}$-(4-phenyl-1H-imidazol-2-yl)acetamide $46(70 \mathrm{mg}, 0.35 \mathrm{mmol})$ was obtained 51 (47 mg, $0.29 \mathrm{mmol}, 84 \%$ yield $)$ as a red solid. ${ }^{1} \mathrm{H}$ NMR $(400 \mathrm{MHz}, \mathrm{MeOD}) \delta 7.62-7.46(\mathrm{~m}, 2 \mathrm{H}), 7.31(\mathrm{t}, J=7.7 \mathrm{~Hz}, 2 \mathrm{H}), 7.16$ $(\mathrm{td}, J=7.5,1.2 \mathrm{~Hz}, 1 \mathrm{H}), 6.91(\mathrm{~s}, 1 \mathrm{H}) \mathrm{ppm} .{ }^{13} \mathrm{C}$ NMR $(125 \mathrm{MHz}$, MeOD) $\delta 150.3,132.9,128.4,128.1,125.6,123.5,111.2 \mathrm{ppm}$. LCMS (ESI+) $\mathrm{m} / z 160.1[\mathrm{M}+\mathrm{H}]^{+}$, retention time $1.45 \mathrm{~min}(100 \%)$. HRMS (ESI+): $m / z$ calculated for $\mathrm{C}_{9} \mathrm{H}_{10} \mathrm{BrN}_{3}[\mathrm{M}+\mathrm{H}]^{+}: 160.0875$. Found: 160.0873. NMR data is in accordance with literature values. ${ }^{37}$ 
4-(4-Morpholinophenyl)-1H-imidazol-2-amine (52). Following general method G, from $\mathrm{N}$-(4-(4-morpholinophenyl)- $1 \mathrm{H}$-imidazol-2yl)acetamide $47(85 \mathrm{mg}, 0.30 \mathrm{mmol})$ was obtained $\mathbf{5 2}(60 \mathrm{mg}, 0.24$ mmol, $82 \%$ yield) as a brown solid. ${ }^{1} \mathrm{H}$ NMR $(400 \mathrm{MHz}, \mathrm{MeOD}) \delta 7.47$ $(\mathrm{d}, J=8.8 \mathrm{~Hz}, 2 \mathrm{H}), 6.96(\mathrm{~d}, J=8.8 \mathrm{~Hz}, 2 \mathrm{H}), 6.78(\mathrm{~s}, 1 \mathrm{H}), 3.91-3.64(\mathrm{~m}$, 4H), 3.19-3.02 (m, 4H) ppm. ${ }^{13} \mathrm{C}$ NMR (125 MHz, MeOD) $\delta 149.9$, 149.8, 129.3, 125.0, 124.5, 115.8, 113.0, 66.6, 49.4 ppm. LCMS (ESI+) $\mathrm{m} / z 245.1[\mathrm{M}+\mathrm{H}]^{+}$, retention time $1.50 \mathrm{~min}(100 \%)$. HRMS (ESI+): $m / z$ calculated for $\mathrm{C}_{13} \mathrm{H}_{17} \mathrm{~N}_{4} \mathrm{O}[\mathrm{M}+\mathrm{H}]^{+}: 245.1402$. Found: 245.1390 .

4-(4-Methoxyphenyl)-1H-imidazol-2-amine (53). Following general method G, from $\mathrm{N}$-(4-(4-methoxyphenyl)-1H-imidazol-2-yl)acetamide $48(83 \mathrm{mg}, 0.36 \mathrm{mmol})$ was obtained $53(65 \mathrm{mg}, 0.34$ mmol, $95 \%$ yield) as a brown solid. ${ }^{1} \mathrm{H}$ NMR (400 MHz, MeOD) $\delta$ 7.54-7.39 (m, 2H), 7.04-6.85 (m, 2H), $6.78(\mathrm{~s}, 1 \mathrm{H}), 3.81(\mathrm{~s}, 3 \mathrm{H}) \mathrm{ppm}$. ${ }^{13} \mathrm{C}$ NMR (100 MHz, MeOD) $\delta 158.3,150.0,125.9,125.0,124.8,113.6$, 109.8, $54.3 \mathrm{ppm}$. LCMS (ESI+) $\mathrm{m} / z 190.2[\mathrm{M}+\mathrm{H}]^{+}$, retention time $1.61 \mathrm{~min}(100 \%)$. HRMS (ESI+): $\mathrm{m} / z$ calculated for $\mathrm{C}_{10} \mathrm{H}_{12} \mathrm{~N}_{3} \mathrm{O}[\mathrm{M}+$ $\mathrm{H}]^{+}:$190.0980. Found: 190.0979. NMR data is in accordance with literature values. ${ }^{37}$

4-(4-Iodophenyl)-1H-imidazol-2-amine (54). Following general method G, from $\mathrm{N}$-(4-(4-iodophenyl)-1H-imidazol-2-yl)acetamide 49 (150 mg, $0.46 \mathrm{mmol}$ ) was obtained 54 (103 mg, $0.36 \mathrm{mmol}, 79 \%$ yield) as a red solid. ${ }^{1} \mathrm{H}$ NMR $\left(500 \mathrm{MHz}, \mathrm{DMSO}-d_{6}\right) \delta 7.58(\mathrm{~d}, J=8.3 \mathrm{~Hz}$, $2 \mathrm{H}), 7.38(\mathrm{~d}, J=8.2 \mathrm{~Hz}, 2 \mathrm{H}), 7.03(\mathrm{~s}, 1 \mathrm{H}), 5.35(\mathrm{br} \mathrm{s}, 2 \mathrm{H}) \mathrm{ppm} .{ }^{13} \mathrm{C}$ NMR (125 MHz, DMSO-d $\left.d_{6}\right) \delta 150.8,137.4,134.6,133.4,126.0,111.1$, $90.2 \mathrm{ppm}$. LCMS (ESI+) $\mathrm{m} / z 286.1[\mathrm{M}+\mathrm{H}]^{+}$, retention time $2.09 \mathrm{~min}$ (100\%). HRMS (ESI+): $m / z$ calculated for $\mathrm{C}_{9} \mathrm{H}_{9} \mathrm{IN}_{3}[\mathrm{M}+\mathrm{H}]^{+}$: 285.9841. Found: 285.9846.

4-(1H-Imidazol-4-yl)phenol (55). 2-Bromo-1-(4-hydroxyphenyl)ethan-1-one $(1.0 \mathrm{~g}, 4.67 \mathrm{mmol})$ was dissolved in formamide $(5 \mathrm{~mL})$, and the reaction mixture was heated at $150{ }^{\circ} \mathrm{C}$ for $24 \mathrm{~h}$. After cooling to $\mathrm{rt}$, the resulting mixture was diluted with EtOAc $(40 \mathrm{~mL})$ and washed with saturated aqueous $\mathrm{NaHCO}_{3}(40 \mathrm{~mL})$. The aqueous layer was extracted with EtOAc $(2 \times 40 \mathrm{~mL})$, and the combined organic layers were dried over $\mathrm{MgSO}_{4}$, filtered, and concentrated to give $\mathbf{5 5}(0.75 \mathrm{~g}$, $4.67 \mathrm{mmol}, 99 \%$ yield) as a brown oil. ${ }^{1} \mathrm{H}$ NMR (400 MHz, MeOD) $\delta$ $8.17(\mathrm{br} \mathrm{s}, 1 \mathrm{H}), 7.68(\mathrm{~d}, J=1.2 \mathrm{~Hz}, 1 \mathrm{H}), 7.64-7.44(\mathrm{~m}, 2 \mathrm{H}), 7.25(\mathrm{~d}, J=$ $1.1 \mathrm{~Hz}, 1 \mathrm{H}), 6.82(\mathrm{~d}, J=8.6 \mathrm{~Hz}, 2 \mathrm{H}) \mathrm{ppm} .{ }^{13} \mathrm{C}$ NMR $(100 \mathrm{MHz}, \mathrm{MeOD})$ $\delta 156.3,135.1,125.8,124.3,115.1 \mathrm{ppm}$. LCMS (ESI+) $\mathrm{m} / z 161.2[\mathrm{M}+$ $\mathrm{H}]^{+}$, retention time $0.54 \mathrm{~min}(100 \%)$. HRMS (ESI $): m / z$ calculated for $\mathrm{C}_{9} \mathrm{H}_{9} \mathrm{~N}_{2} \mathrm{O}[\mathrm{M}+\mathrm{H}]^{+}:$161.0715. Found: 161.0720. NMR data is in accordance with literature values. ${ }^{38}$

4-(4-Methoxyphenyl)-1-methyl-1H-imidazole (56). To a solution of $55(2.77 \mathrm{~g}, 17 \mathrm{mmol})$ in DMF $(20 \mathrm{~mL})$ containing cesium carbonate $(12.4 \mathrm{~g}, 38 \mathrm{mmol})$ at $\mathrm{rt}$ was added iodomethane $(2.4 \mathrm{~mL}, 38 \mathrm{mmol})$. The reaction mixture was stirred at $\mathrm{rt}$ for $8 \mathrm{~h}$. The reaction mixture was then cooled to $0{ }^{\circ} \mathrm{C}$ and quenched with $\mathrm{H}_{2} \mathrm{O}(70 \mathrm{~mL})$ and extracted with EtOAc $(3 \times 60 \mathrm{~mL})$. The combined organic layers were washed with brine $(3 \times 100 \mathrm{~mL})$, dried over $\mathrm{MgSO}_{4}$, filtered, and concentrated to give $56\left(2.8 \mathrm{~g}, 15 \mathrm{mmol}, 88 \%\right.$ yield) as a brown solid. ${ }^{1} \mathrm{H}$ NMR (400 $\left.\mathrm{MHz}, \mathrm{CDCl}_{3}\right) \delta 7.71(\mathrm{~d}, J=8.8 \mathrm{~Hz}, 2 \mathrm{H}), 7.46(\mathrm{~d}, J=1.3 \mathrm{~Hz}, 1 \mathrm{H}), 7.10$ $(\mathrm{d}, J=1.4 \mathrm{~Hz}, 1 \mathrm{H}), 6.94(\mathrm{~d}, J=8.9 \mathrm{~Hz}, 2 \mathrm{H}), 3.85(\mathrm{~s}, 3 \mathrm{H}), 3.73(\mathrm{~s}, 3 \mathrm{H})$ ppm. ${ }^{13} \mathrm{C}$ NMR $\left(100 \mathrm{MHz}, \mathrm{CDCl}_{3}\right) \delta 158.6,142.4,137.8,127.2,126.0$, 114.8, 114.0, 55.3, 33.5. LCMS (ESI+) $m / z 189.2[\mathrm{M}+\mathrm{H}]^{+}$, retention time $1.38 \mathrm{~min}(100 \%)$. HRMS (ESI+): $m / z$ calculated for $\mathrm{C}_{11} \mathrm{H}_{13} \mathrm{~N}_{2} \mathrm{O}$ $[\mathrm{M}+\mathrm{H}]^{+}:$189.1028. Found: 189.1031 . NMR data is in accordance with literature values. ${ }^{41}$

4-(1-Methyl-1H-imidazol-4-yl)phenol (57). A solution of 4-(4methoxyphenyl)-1-methyl-1H-imidazole $56(1.21 \mathrm{~g}, 6.42 \mathrm{mmol})$ in anhydrous DCM $(30 \mathrm{~mL})$ at $-78{ }^{\circ} \mathrm{C}$ was treated with $\mathrm{BBr}_{3}(16 \mathrm{~mL}$, $16.05 \mathrm{mmol}, 1 \mathrm{M}$ in DCM). The reaction mixture was stirred at $-78^{\circ} \mathrm{C}$ for $10 \mathrm{~min}$ and $2 \mathrm{~h}$ at $\mathrm{rt}$. The reaction mixture was then cooled to $-78^{\circ} \mathrm{C}$ and quenched with $\mathrm{MeOH}(4 \mathrm{~mL})$. The solvents were then removed under reduced pressure, and the crude product was redissolved in EtOAc $(50 \mathrm{~mL})$ and washed with saturated $\mathrm{NaHCO}_{3}$ solution. The aqueous phase was extracted with EtOAc $(2 \times 50 \mathrm{~mL})$, and the combined organic fractions were dried with anhydrous $\mathrm{MgSO}_{4}$ and filtered off, and the solvent was removed under vacuum to give $\mathbf{5 7}$ (1.30 g, $6.17 \mathrm{mmol}$, $96 \%$ yield) as a brown solid, which was used in the next step without further purification. ${ }^{1} \mathrm{H} \mathrm{NMR}(400 \mathrm{MHz}, \mathrm{MeOD}) \delta 8.99-$ $8.80(\mathrm{~m}, 1 \mathrm{H}), 7.77(\mathrm{~d}, J=1.6 \mathrm{~Hz}, 1 \mathrm{H}), 7.55(\mathrm{~d}, J=8.7 \mathrm{~Hz}, 2 \mathrm{H}), 6.93(\mathrm{~d}, J$ $=8.8 \mathrm{~Hz}, 2 \mathrm{H}), 3.99(\mathrm{~s}, 3 \mathrm{H}) \mathrm{ppm} .{ }^{13} \mathrm{C}$ NMR $(100 \mathrm{MHz}, \mathrm{MeOD}) \delta 159.1$, 135.1, 134.6, 126.9, 117.3, 117.2, 115.8, 35.0 ppm. LCMS (ESI+) $\mathrm{m} / z$ $175.1[\mathrm{M}+\mathrm{H}]^{+}$, retention time $1.09 \mathrm{~min}(100 \%)$. HRMS (ESI+): $\mathrm{m} / z$ calculated for $\mathrm{C}_{10} \mathrm{H}_{11} \mathrm{~N}_{2} \mathrm{O}[\mathrm{M}+\mathrm{H}]^{+}$: 175.0871. Found: 175.0870 .

Methyl 2-(4-(1-Methyl-1H-imidazol-4-yl)phenoxy)propanoate (58). $\mathrm{Cs}_{2} \mathrm{CO}_{3}(3.46 \mathrm{~g}, 10.62 \mathrm{mmol})$ and methyl 2-bromopropanoate $(1.29 \mathrm{~g}, 6.81 \mathrm{mmol})$ were added to a solution of phenol derivative $\mathbf{5 7}$ $(1.12 \mathrm{~g}, 5.32 \mathrm{mmol})$ in anhydrous DMF $(10 \mathrm{~mL})$, and the mixture was stirred at $\mathrm{rt}$ for $1 \mathrm{~h}$ and at $60^{\circ} \mathrm{C}$ for $5 \mathrm{~h}$. After cooling to rt, the reaction was diluted with water $(80 \mathrm{~mL})$ and extracted with EtOAc $(2 \times 80 \mathrm{~mL})$. The combined organic layers were washed with brine $(3 \times 100 \mathrm{~mL})$, dried over $\mathrm{MgSO}_{4}$, filtered, and concentrated. The crude product was purified by flash chromatography $(0-20 \% \mathrm{v} / \mathrm{v} \mathrm{MeOH}$ in DCM) to give $58(1.30 \mathrm{~g}, 4.99 \mathrm{mmol}, 92 \%$ yield $)$ as an orange oil. ${ }^{1} \mathrm{H}$ NMR $(400 \mathrm{MHz}$, $\left.\mathrm{CDCl}_{3}\right) \delta 7.74-7.61(\mathrm{~m}, 2 \mathrm{H}), 7.45(\mathrm{~d}, J=1.3 \mathrm{~Hz}, 1 \mathrm{H}), 7.08(\mathrm{~d}, J=1.4$ $\mathrm{Hz}, 1 \mathrm{H}), 6.96-6.81(\mathrm{~m}, 2 \mathrm{H}), 4.81(\mathrm{q}, J=6.8 \mathrm{~Hz}, 1 \mathrm{H}), 3.77(\mathrm{~s}, 3 \mathrm{H}), 3.71$ $(\mathrm{s}, 3 \mathrm{H}), 1.64(\mathrm{~d}, J=6.8 \mathrm{~Hz}, 3 \mathrm{H}) \mathrm{ppm} .{ }^{13} \mathrm{C} \mathrm{NMR}\left(100 \mathrm{MHz}, \mathrm{CDCl}_{3}\right) \delta$ $172.8,156.5,142.1,137.8,128.1,126.0,115.3,115.1,72.7,52.3,33.5$, $18.6 \mathrm{ppm}$. LCMS (ESI +$) \mathrm{m} / z 261.3[\mathrm{M}+\mathrm{H}]^{+}$, retention time $1.50 \mathrm{~min}$ (100\%). HRMS (ESI+): $m / z$ calculated for $\mathrm{C}_{14} \mathrm{H}_{17} \mathrm{~N}_{2} \mathrm{O}_{3}[\mathrm{M}+\mathrm{H}]^{+}$: 261.1239. Found: 261.1232 .

2-(4-(1-Methyl-1H-imidazol-4-yl)phenoxy)propanoic Acid (59). Methyl 2-(4-(1-methyl-1H-imidazol-4-yl)phenoxy)propanoate $\mathbf{5 8}$ $(0.53 \mathrm{~g}, 2.04 \mathrm{mmol})$ was dissolved in a $2: 1 \mathrm{v} / \mathrm{v}$ mixture of THF and $\mathrm{H}_{2} \mathrm{O}(7.5 \mathrm{~mL})$, and then $\mathrm{NaOH}(0.16 \mathrm{~g}, 4.08 \mathrm{mmol})$ was added. The reaction mixture was heated at $80{ }^{\circ} \mathrm{C}$ for $40 \mathrm{~min}$. After the reaction mixture was allowed to cool to $\mathrm{rt}$, the solvents were removed. The mixture was then diluted with $\mathrm{H}_{2} \mathrm{O}(5 \mathrm{~mL})$ and acidified to $\mathrm{pH}$ 7-8 using $1 \mathrm{~N} \mathrm{HCl}$. The mixture was cooled, and the resulting precipitate was collected by filtration, washed with water $(2 \times 3 \mathrm{~mL})$ and petroleum ether $(2 \times 3 \mathrm{~mL})$, and dried in vacuo to afford acid $59(0.33 \mathrm{~g}, 1.33 \mathrm{mmol}$, $65 \%$ yield $)$ as a white solid. ${ }^{1} \mathrm{H}$ NMR $\left(400 \mathrm{MHz}\right.$, DMSO- $\left.d_{6}\right) \delta 7.69-$ $7.55(\mathrm{~m}, 3 \mathrm{H}), 7.46(\mathrm{~d}, J=1.3 \mathrm{~Hz}, 1 \mathrm{H}), 6.84(\mathrm{~d}, J=8.8 \mathrm{~Hz}, 2 \mathrm{H}), 4.81(\mathrm{q}, J$ $=6.8 \mathrm{~Hz}, 1 \mathrm{H}), 3.66(\mathrm{~s}, 3 \mathrm{H}), 1.49(\mathrm{~d}, J=6.7 \mathrm{~Hz}, 3 \mathrm{H}) .{ }^{13} \mathrm{C}$ NMR $(100$ $\left.\mathrm{MHz}, \mathrm{DMSO}-d_{6}\right) \delta 173.3,156.1,140.4,138.2,127.8,125.4,115.8$, $114.8,71.7,33.1,18.4$. LCMS (ESI+) $m / z 247.2\left[\mathrm{M}+\mathrm{H}^{+}\right.$, retention time $1.43 \mathrm{~min}(100 \%)$. HRMS (ESI+): $m / z$ calculated for $\mathrm{C}_{13} \mathrm{H}_{15} \mathrm{~N}_{2} \mathrm{O}_{3}$ $[\mathrm{M}+\mathrm{H}]^{+}:$247.1083. Found: 247.1080.

(S)-2-(4-(1-Methyl-1H-imidazol-4-yl)phenoxy)propanoic Acid ((S)59). To a solution of $57(212 \mathrm{mg}, 1.21 \mathrm{mmol})$ in anhydrous THF (5 $\mathrm{mL})$ was added ethyl D-lactate $(215 \mathrm{mg}, 1.82 \mathrm{mmol})$. After the reaction mixture was cooled to $0^{\circ} \mathrm{C}, \mathrm{PPh}_{3}(478 \mathrm{mg}, 1.82 \mathrm{mmol})$ and DEAD (286 $\mu \mathrm{L}, 1.82 \mathrm{mmol}$ ) were added, and the reaction mixture was stirred for 16 $\mathrm{h}$ at $\mathrm{rt}$. The reaction mixture was poured into ice-water $(40 \mathrm{~mL})$ and extracted with DCM $(3 \times 50 \mathrm{~mL})$. The combined organic layers were washed with brine, dried over anhydrous $\mathrm{MgSO}_{4}$, filtered, and concentrated. The crude product was purified by flash chromatography $(0-15 \% \mathrm{v} / \mathrm{v} \mathrm{MeOH}$ in DCM $)$ to give ethyl $(S)-2-(4-(1-m e t h y l-1 H-$ imidazol-4-yl)phenoxy)propanoate as an orange solid. LCMS (ESI+) $m / z 275.3[\mathrm{M}+\mathrm{H}]^{+}$, retention time $2.06 \mathrm{~min}$ (94\%). Ethyl (S)-2-(4-(1methyl-1H-imidazol-4-yl)phenoxy)propanoate $(200 \mathrm{mg}, 0.73 \mathrm{mmol})$ was dissolved in a $2: 1 \mathrm{v} / \mathrm{v}$ mixture of THF and $\mathrm{H}_{2} \mathrm{O}(7.5 \mathrm{~mL})$, and then $\mathrm{NaOH}(58 \mathrm{mg}, 1.46 \mathrm{mmol}$ ) was added. The reaction mixture was stirred at $\mathrm{rt}$ for $3 \mathrm{~h}$, and the solvents were removed. The residue was dissolved in EtOAc $(40 \mathrm{~mL})$ and then extracted with $\mathrm{H}_{2} \mathrm{O}(40 \mathrm{~mL})$. The aqueous layer was acidified to $\mathrm{pH} 7-8$ using $1 \mathrm{~N} \mathrm{HCl}$. The mixture was cooled, and the resulting precipitate was collected by filtration, washed with water $(2 \times 3 \mathrm{~mL})$ and petroleum ether $(2 \times 3 \mathrm{~mL})$, and dried in vacuo to afford acid $(S)-59(100 \mathrm{mg}, 0.40 \mathrm{mmol}, 56 \%$ yield $)$ as a white solid. $[\alpha]_{\mathrm{D}}^{25}$ $-51.6\left(c 1.0, \mathrm{CHCl}_{3}\right)$. LCMS (ESI +$) \mathrm{m} / z 247.2\left[\mathrm{M}+\mathrm{H}^{+}\right.$, retention time $1.43 \mathrm{~min}$ (100\%). HRMS (ESI+): $m / z$ calculated for $\mathrm{C}_{13} \mathrm{H}_{15} \mathrm{~N}_{2} \mathrm{O}_{3}$ $[\mathrm{M}+\mathrm{H}]^{+}:$247.1083. Found: 247.1079.

4-(4-Bromophenyl)oxazol-2-amine (61). A mixture of 2-bromo-1(4-bromophenyl)ethanone ( $200 \mathrm{mg}, 0.72 \mathrm{mmol}$ ) and urea ( $435 \mathrm{mg}, 7.2$ $\mathrm{mmol})$ in anhydrous acetonitrile $(5 \mathrm{~mL})$ was heated at $80^{\circ} \mathrm{C}$ for $18 \mathrm{~h}$. The solvent was removed, and the residue was purified by flash chromatography $(0-10 \% \mathrm{v} / \mathrm{v} \mathrm{MeOH}$ in DCM $)$ to afford $61(134 \mathrm{mg}$, $0.56 \mathrm{mmol}, 78 \%$ yield) as a yellow solid. ${ }^{1} \mathrm{H}$ NMR $(400 \mathrm{MHz}, \mathrm{MeOD}) \delta$ $7.68(\mathrm{~s}, 1 \mathrm{H}), 7.59-7.42(\mathrm{~m}, 4 \mathrm{H}) \mathrm{ppm} .{ }^{13} \mathrm{C}$ NMR (125 MHz, MeOD) $\delta$ 
163.9, 139.8, 132.7, 132.1, 128.8, 127.9, 122.1 ppm. LCMS (ESI+) $\mathrm{m} / z$ $238.8[\mathrm{M}+\mathrm{H}]^{+}$, retention time $1.95 \mathrm{~min}(100 \%)$. HRMS (ESI+): $\mathrm{m} / \mathrm{z}$ calculated for $\mathrm{C}_{9} \mathrm{H}_{8} \mathrm{BrN}_{2} \mathrm{O}[\mathrm{M}+\mathrm{H}]^{+}$: 238.9820. Found: 238.9816 .

2. Enzyme Assay. The activity of Mth IMPDH $\triangle \mathrm{CBS}$ was determined using a plate reader by monitoring the production of $\mathrm{NADH}$ in absorbance at $340 \mathrm{~nm}$ and corrected for noncatalyzed chemical reactions in the absence of $M t h \mathrm{IMPDH} \triangle \mathrm{CBS}$. All the measurements were done in the assay buffer ( $50 \mathrm{mM}$ Tris $\mathrm{HCl} \mathrm{pH} 8,1 \mathrm{mM}$ DTT, $1 \mathrm{mM}$ EDTA, and $100 \mathrm{mM} \mathrm{KCl}$ ) at $37^{\circ} \mathrm{C}$ with $20 \mathrm{nM} \mathrm{Mth} \mathrm{IMPDH} \Delta \mathrm{CBS}, 2.8$ $\mathrm{mMNAD}^{+}$, and $1 \mathrm{mM} \mathrm{IMP}$ in a total of $150 \mu \mathrm{L}$ volume in a 96 well platebased format, and data were collected for $32 \mathrm{~min}$. The reaction was initiated by the addition of the substrate, IMP, at a concentration of 1 $\mathrm{mM}$. All reactions were performed in triplicate. Prior to reaction initiation, the compounds were preincubated in a buffer with enzyme for $5 \mathrm{~min}$. The inhibitors were dissolved in DMSO- $d_{6}$ and diluted to a final concentration of $1 \% \mathrm{v} / \mathrm{v}$ in experimental reactions.

$\mathrm{IC}_{50}$ values were calculated by plotting the percentage of inhibition against the logarithm of inhibitor concentration, and dose-response curves were fitted using Prism software (GraphPad).

The $K_{\mathrm{i}}$ value for $\mathrm{NAD}^{+}$was determined at a constant saturating IMP concentration $(1 \mathrm{mM})$ and five different concentrations of $\mathrm{NAD}^{+}(0.35$, $0.70,1.0,1.4$, and $2.8 \mathrm{mM}$ ) in the presence of increasing concentrations of inhibitor. The value of $K_{\mathrm{i}}$ for IMP was determined at fixed saturating concentration of $\mathrm{NAD}^{+}(2.8 \mathrm{mM})$ and different concentrations of IMP $(0.12,0.18,0.25,0.5$, and $1 \mathrm{mM})$ and inhibitor.

The initial velocities at various inhibitor concentrations were determined based on the slope in the linear part of each reaction containing the inhibitor and the uninhibited reaction. To determine the inhibition constant ( $K_{\mathrm{i}}$ values), the initial rate data versus substrate concentration at different inhibitor concentrations were fit using Prism software (GraphPad) to equations for uncompetitive or mixed inhibition. For each inhibitor concentration, the reciprocal of enzyme reaction velocity versus the reciprocal of the substrate concentration was plotted in a Lineweaver-Burk plot to determine the pattern of inhibition.

3. Protein Purification, Crystallization, and Data Collection of Mth IMPDH $\triangle$ CBS. Mth IMPDH was expressed, purified, and crystallized as previously described. ${ }^{24,25}$ Briefly, hexahistidine tagged Mth IMPDH $\triangle$ CBS in pHat2 was expressed overnight in BL21 DE3 (NEB) cells at $18^{\circ} \mathrm{C}$ by addition of $500 \mu \mathrm{M}$ IPTG. Cells were lysed in 50 $\mathrm{mM}$ Hepes, $\mathrm{pH} 8.0,500 \mathrm{mM} \mathrm{NaCl}, 5 \%$ glycerol, $10 \mathrm{mM} \beta$ mercaptoethanol, and $20 \mathrm{mM}$ imidazole, and the recombinant protein purified using a Hi-Trap IMAC FF column (GE Healthcare) charged with nickel and an elution gradient of up to $300 \mathrm{mM}$ imidazole. The hexahistidine tag was cleaved by TEV protease, and the purified $M t h$ IMPDH $\triangle$ CBS was obtained by negative nickel gravity-flow purification $^{42}$ and size exclusion chromatography on a Superdex 200 gel filtration column equilibrated in $20 \mathrm{mM}$ Hepes $\mathrm{pH} 8.0,500 \mathrm{mM}$ $\mathrm{NaCl}, 5 \%$ glycerol, and $1 \mathrm{mM}$ TCEP step. The recombinant $M$ th IMPDH $\triangle$ CBS was then concentrated to $12.5 \mathrm{mg} / \mathrm{mL}$ for crystallization.

Mth IMPDH $\Delta$ CBS protein crystallized in $1 \mu \mathrm{L}+1 \mu \mathrm{L}$ hanging drops with $100 \mathrm{mM}$ sodium acetate, $\mathrm{pH} 5.5,200 \mathrm{mM}$ calcium chloride, and 8$14 \%$ isopropanol. Crystals were soaked overnight in drops of well solution $+5 \mathrm{mM}$ IMP and either $5 \mathrm{mM}$ Fragment 2 or Compound 1 or 1 $\mathrm{mM}$ Compound 31. Crystals were cryoprotected by passing through drops containing well solution $+25 \%$ glycerol and flash-frozen in liquid nitrogen. Data were collected from the crystals at Diamond Light Source beamline.

4. Structure Solution, Ligand Fitting, and Refinement. Data were processed using $\mathrm{XDS}^{43}$ and Pointless (CCP4). To solve the structure, molecular replacement was performed with Phenix Phaser ${ }^{44}$ using a previously solved IMP-bound $M t h$ IMPDH $\triangle \mathrm{CBS}$ structure as a probe (PDB IDs: 5J5R; 5K4X; 5K4Z). Refinement was performed using Phenix.refine and manually in Coot. ${ }^{45}$ IMP and the inhibitors were sequentially fitted into the density using the LigandFit function of Phenix, and the structures were manually refined further using Coot. Information regarding the crystallographic statistics can be found in Table S2. Protein-ligand interactions were analyzed using Arpeggio ${ }^{46}$ and CSM-Lig. ${ }^{47,48}$ Compound properties were evaluated using pkCSM. ${ }^{49}$ All figures made using Pymol (Schrodinger).

5. Drug Susceptibility Testing against Mtb. An Alamar Blue fluorescence-based broth microdilution assay was used to assess the minimum inhibitory concentration (MIC) of compounds against $\mathrm{M} t b$ $\mathrm{H} 37 \mathrm{Rv}$, as described previously. ${ }^{25,50}$ Briefly, $M t b \mathrm{H} 37 \mathrm{Rv}$ was grown in standard Middlebrook 7H9 broth (BD) supplemented with OADC (BD), $0.2 \%$ glycerol, and $0.05 \%$ Tween- 80 to midexponential phase. Compounds dissolved in DMSO (1\%) were tested in clear-bottomed, round-well 96-well microtiter plates at eight different concentrations using the standard anti-TB drugs, rifampin and isoniazid, as positive controls. An inoculum of $\sim 10^{5}$ bacteria was added to each well, and the plates were incubated at $37^{\circ} \mathrm{C}$ for $7 \mathrm{~d}$. On day $7,10 \mu \mathrm{L}$ of Alamar Blue (Invitrogen) was added to each well, and plates were further incubated at $37^{\circ} \mathrm{C}$ for $24 \mathrm{~h}$. The fluorescence (excitation $544 \mathrm{~nm}$; emission 590 $\mathrm{nm}$ ) was measured in a FLUOstar OPTIMA plate reader (BMG LABTECH, Offenberg, Germany). Data were normalized to the minimum and maximum inhibition controls to generate a dose response curve (\% inhibition) from which the $\mathrm{MIC}_{90}$ was determined.

\section{ASSOCIATED CONTENT}

\section{Supporting Information}

The Supporting Information is available free of charge on the ACS Publications website at DOI: 10.1021/acs.jmedchem.7b01622.

${ }^{1} \mathrm{H},{ }^{13} \mathrm{C}$, and 2D NMR spectra of all new compounds, supplementary Figures S1-S2, whole-cell activity of compounds against M. tuberculosis H37Rv (Table S1), and X-ray data collection and refinement statistics (Table S2) (PDF)

Molecular formula strings data file for all chemical structures mentioned in the manuscript (CSV)

\section{AUTHOR INFORMATION}

\section{Corresponding Authors}

*T.L.B. email: tom@cryst.bioc.cam.ac.uk.

*D.B.A: phone, +61 3903 54794; e-mail, david.ascher@unimelb. edu.au.

*C.A.: phone, +44 (0) 1223 336405; e-mail, ca26@cam.ac.uk. ORCID $\odot$

Ana Trapero: 0000-0003-4526-7895

Anthony G. Coyne: 0000-0003-0205-5630

Valerie Mizrahi: 0000-0003-4824-9115

Chris Abell: 0000-0001-9174-1987

Present Address

\#(V.S.) H3D Drug Discovery and Development Centre, Department of Chemistry and Institute of Infectious Disease and Molecular Medicine, University of Cape Town, Rondebosch 7701, Cape Town, South Africa.

\section{Notes}

The authors declare no competing financial interest.

Additional data related to this publication is available at the University of Cambridge data repository: https://doi.org/ 10.17863/CAM.20512. Structures have been deposited in the Protein Data Bank (PDB codes 5OU1 for IMPDH:IMP:Compound 1; 5OU2 for IMPDH:IMP:Compound 2 and 5OU3 for IMPDH:IMP:Compound 31 complex structures). Authors will release the atomic coordinates and experimental data upon article publication.

\section{ACKNOWLEDGMENTS}

This work was supported by the Bill and Melinda Gates Foundation (Hit-TB) and FP7 European Project MM4TB Grant 
no. 260872. D.B.A was supported by a C. J. Martin Research Fellowship from the National Health and Medical Research Council of Australia (APP1072476) and the Jack Brockhoff Foundation (JBF 4186, 2016). D.B.A. and T.L.B. were also funded by a Newton Fund RCUK-CONFAP Grant awarded by The Medical Research Council and Fundação de Amparo à Pesquisa do Estado de Minas Gerais (MR/M026302/1). V.M. and V.S. were also supported by grants from the HHMI (Senior International Research Scholars grant to V.M.), the South African Medical Research Council, and the National Research Foundation.

\section{ABBREVIATIONS USED}

TB, tuberculosis; Mycobacterium tuberculosis, Mtb; MDR, multidrug resistant; XDR, extensively drug resistant; IMPDH, inosine-5'-monophosphate dehydrogenase; IMP, inosine $5^{\prime}$ monophosphate; CBS, cystathionine $\beta$-synthase; XMP, xanthosine monophosphate; $\mathrm{NAD}^{+}$, nicotinamide adenine dinucleotide; Mth, Mycobacterium thermoresistible; MIC, minimal inhibitory concentration.; WHO, World Health Organization

\section{REFERENCES}

(1) WHO. Tuberculosis: Fact sheet; World Health Organization 2016: Geneva, Switzerland. 2016.

(2) Onyebujoh, P.; Zumla, A.; Ribeiro, I.; Rustomjee, R.; Mwaba, P.; Gomes, M.; Grange, J. M. Treatment of tuberculosis: present status and future prospects. Bull. World Health Organ. 2005, 83, 857-865.

(3) Orenstein, E. W.; Basu, S.; Shah, N. S.; Andrews, J. R.; Friedland, G. H.; Moll, A. P.; Gandhi, N. R.; Galvani, A. P. Treatment outcomes among patients with multidrug-resistant tuberculosis: systematic review and meta-analysis. Lancet Infect. Dis. 2009, 9, 153-161.

(4) Ratcliffe, A. J. Inosine 5'-monophosphate dehydrogenase inhibitors for the treatment of autoimmune diseases. Curr. Opin. Drug Discovery Dev. 2006, 9, 595-605.

(5) Chen, L.; Pankiewicz, K. W. Recent development of IMP dehydrogenase inhibitors for the treatment of cancer. Curr. Opin. Drug Discovery Dev. 2007, 10, 403-412.

(6) Olah, E.; Kokeny, S.; Papp, J.; Bozsik, A.; Keszei, M. Modulation of cancer pathways by inhibitors of guanylate metabolism. Adv. Enzyme Regul. 2006, 46, 176-190.

(7) Nair, V.; Shu, Q. Inosine monophosphate dehydrogenase as a probe in antiviral drug discovery. Antiviral Chem. Chemother. 2007, 18, $245-258$.

(8) Shu, Q.; Nair, V. Inosine monophosphate dehydrogenase (IMPDH) as a target in drug discovery. Med. Res. Rev. 2008, 28, 219232.

(9) Shah, C. P.; Kharkar, P. S. Inosine 5'-monophosphate dehydrogenase inhibitors as antimicrobial agents: recent progress and future perspectives. Future Med. Chem. 2015, 7, 1415-1429.

(10) Hedstrom, L.; Liechti, G.; Goldberg, J. B.; Gollapalli, D. R. The antibiotic potential of prokaryotic IMP dehydrogenase inhibitors. Curr. Med. Chem. 2011, 18, 1909-1918.

(11) Hedstrom, L. IMP dehydrogenase: structure, mechanism, and inhibition. Chem. Rev. 2009, 109, 2903-2928.

(12) Jackson, R. C.; Weber, G.; Morris, H. P. IMP dehydrogenase, an enzyme linked with proliferation and malignancy. Nature 1975, 256, 331-333.

(13) Gilbert, H. J.; Lowe, C. R.; Drabble, W. T. Inosine 5'monophosphate dehydrogenase of Escherichia coli. Purification by affinity chromatography, subunit structure and inhibition by guanosine 5'-monophosphate. Biochem. J. 1979, 183, 481-494.

(14) Lee, S. A.; Gallagher, L. A.; Thongdee, M.; Staudinger, B. J.; Lippman, S.; Singh, P. K.; Manoil, C. General and condition-specific essential functions of Pseudomonas aeruginosa. Proc. Natl. Acad. Sci. U. S. A. 2015, 112, 5189-5194.

(15) Valentino, M. D.; Foulston, L.; Sadaka, A.; Kos, V. N.; Villet, R. A.; Santa Maria, J., Jr.; Lazinski, D. W.; Camilli, A.; Walker, S.; Hooper, D.
C.; Gilmore, M. S. Genes contributing to Staphylococcus aureus fitness in abscess- and infection-related ecologies. mBio 2014, 5, e01729-14.

(16) Sassetti, C. M.; Boyd, D. H.; Rubin, E. J. Genes required for mycobacterial growth defined by high density mutagenesis. Mol. Microbiol. 2003, 48, 77-84.

(17) Hedstrom, L. The bare essentials of antibiotic target validation. ACS Infect. Dis. 2017, 3, 2-4.

(18) Petrelli, R.; Vita, P.; Torquati, I.; Felczak, K.; Wilson, D. J.; Franchetti, P.; Cappellacci, L. Novel inhibitors of inosine monophosphate dehydrogenase in patent literature of the last decade. Recent Pat. Anti-Cancer Drug Discovery 2013, 8, 103-125.

(19) Makowska-Grzyska, M.; Kim, Y.; Wu, R.; Wilton, R.; Gollapalli, D. R.; Wang, X. K.; Zhang, R.; Jedrzejczak, R.; Mack, J. C.; Maltseva, N.; Mulligan, R.; Binkowski, T. A.; Gornicki, P.; Kuhn, M. L.; Anderson, W. F.; Hedstrom, L.; Joachimiak, A. Bacillus anthracis inosine $5^{\prime}$ monophosphate dehydrogenase in action: the first bacterial series of structures of phosphate ion-, substrate-, and product-bound complexes. Biochemistry 2012, 51, 6148-6163.

(20) Usha, V.; Gurcha, S. S.; Lovering, A. L.; Lloyd, A. J.; Papaemmanouil, A.; Reynolds, R. C.; Besra, G. S. Identification of novel diphenyl urea inhibitors of Mt-GuaB2 active against. Microbiology 2011, 157, 290-299.

(21) Makowska-Grzyska, M.; Kim, Y.; Gorla, S. K.; Wei, Y.; Mandapati, K.; Zhang, M.; Maltseva, N.; Modi, G.; Boshoff, H. I.; Gu, M.; Aldrich, C.; Cuny, G. D.; Hedstrom, L.; Joachimiak, A. Mycobacterium tuberculosis IMPDH in complexes with substrates, products and antitubercular compounds. PLoS One 2015, 10, No. e0138976.

(22) Chen, L.; Wilson, D. J.; Xu, Y.; Aldrich, C. C.; Felczak, K.; Sham, Y. Y.; Pankiewicz, K. W. Triazole-linked inhibitors of inosine monophosphate dehydrogenase from human and. J. Med. Chem. 2010, 53, 4768-4778.

(23) Usha, V.; Hobrath, J. V.; Gurcha, S. S.; Reynolds, R. C.; Besra, G. S. Identification of novel Mt-Guab2 inhibitor series active against $M$. tuberculosis. PLoS One 2012, 7, No. e33886.

(24) Park, Y.; Pacitto, A.; Bayliss, T.; Cleghorn, L. A.; Wang, Z.; Hartman, T.; Arora, K.; Ioerger, T. R.; Sacchettini, J.; Rizzi, M.; Donini, S.; Blundell, T. L.; Ascher, D. B.; Rhee, K. Y.; Breda, A.; Zhou, N.; Dartois, V.; Jonnala, S. R.; Via, L. E.; Mizrahi, V.; Epemolu, O.; Stojanovski, L.; Simeons, F. R.; Osuna-Cabello, M.; Ellis, L.; MacKenzie, C. J.; Smith, A. R.; Davis, S. H.; Murugesan, D.; Buchanan, K. I.; Turner, P. A.; Huggett, M.; Zuccotto, F.; Rebollo-Lopez, M. J.; LafuenteMonasterio, M. J.; Sanz, O.; Santos Diaz, G.; Lelievre, J.; Ballell, L.; Selenski, C.; Axtman, M.; Ghidelli-Disse, S.; Pflaumer, H.; Boesche, M.; Drewes, G.; Freiberg, G.; Kurnick, M. D.; Srikumaran, M.; Kempf, D. J.; Green, S. R.; Ray, P. C.; Read, K. D.; Wyatt, P. G.; Barry Rd, C. E.; Boshoff, H. I. Essential but not vulnerable: indazole sulfonamides targeting inosine monophosphate dehydrogenase as potential leads against. ACS Infect. Dis. 2017, 3, 18-23.

(25) Singh, V.; Donini, S.; Pacitto, A.; Sala, C.; Hartkoorn, R. C.; Dhar, N.; Keri, G.; Ascher, D. B.; Mondesert, G.; Vocat, A.; Lupien, A.; Sommer, R.; Vermet, H.; Lagrange, S.; Buechler, J.; Warner, D. F.; McKinney, J. D.; Pato, J.; Cole, S. T.; Blundell, T. L.; Rizzi, M.; Mizrahi, $\mathrm{V}$. The inosine monophosphate dehydrogenase, GuaB2, is a vulnerable new bactericidal drug target for tuberculosis. ACS Infect. Dis. 2017, 3, 517.

(26) Cox, J. A.; Mugumbate, G.; Del Peral, L. V.; Jankute, M.; Abrahams, K. A.; Jervis, P.; Jackenkroll, S.; Perez, A.; Alemparte, C.; Esquivias, J.; Lelievre, J.; Ramon, F.; Barros, D.; Ballell, L.; Besra, G. S. Novel inhibitors of Mycobacterium tuberculosis GuaB2 identified by a target based high-throughput phenotypic screen. Sci. Rep. 2016, 6, 38986.

(27) Moffat, J. G.; Vincent, F.; Lee, J. A.; Eder, J.; Prunotto, M. Opportunities and challenges in phenotypic drug discovery: an industry perspective. Nat. Rev. Drug Discovery 2017, 16, 531-543.

(28) Koul, A.; Arnoult, E.; Lounis, N.; Guillemont, J.; Andries, K. The challenge of new drug discovery for tuberculosis. Nature 2011, 469, 483-490. 
(29) Payne, D. J.; Gwynn, M. N.; Holmes, D. J.; Pompliano, D. L. Drugs for bad bugs: confronting the challenges of antibacterial discovery. Nat. Rev. Drug Discovery 2007, 6, 29-40.

(30) Scott, D. E.; Coyne, A. G.; Hudson, S. A.; Abell, C. Fragmentbased approaches in drug discovery and chemical biology. Biochemistry 2012, 51, 4990-5003.

(31) Mendes, V.; Blundell, T. L. Targeting tuberculosis using structureguided fragment-based drug design. Drug Discovery Today 2017, 22, $546-554$.

(32) Marchetti, C.; Chan, D. S.; Coyne, A. G.; Abell, C. Fragmentbased approaches to TB drugs. Parasitology 2018, 145, 184-195.

(33) Wei, Y.; Kuzmic, P.; Yu, R.; Modi, G.; Hedstrom, L. Inhibition of inosine-5'-monophosphate dehydrogenase from Bacillus anthracis: Mechanism revealed by pre-steady-state kinetics. Biochemistry 2016, 55, 5279-5288.

(34) Dunkern, T.; Prabhu, A.; Kharkar, P. S.; Goebel, H.; Rolser, E.; Burckhard-Boer, W.; Arumugam, P.; Makhija, M. T. Virtual and experimental high-throughput screening (HTS) in search of novel inosine 5 '-monophosphate dehydrogenase II (IMPDH II) inhibitors. J. Comput.-Aided Mol. Des. 2012, 26, 1277-1292.

(35) Gorla, S. K.; Kavitha, M.; Zhang, M.; Chin, J. E.; Liu, X.; Striepen, B.; Makowska-Grzyska, M.; Kim, Y.; Joachimiak, A.; Hedstrom, L.; Cuny, G. D. Optimization of benzoxazole-based inhibitors of Cryptosporidium parvum inosine 5 '-monophosphate dehydrogenase. J. Med. Chem. 2013, 56, 4028-4043.

(36) Kitagawa, H.; Ozawa, T.; Takahata, S.; Iida, M.; Saito, J.; Yamada, M. Phenylimidazole derivatives of 4-pyridone as dual inhibitors of bacterial enoyl-acyl carrier protein reductases FabI and FabK. J. Med. Chem. 2007, 50, 4710-4720.

(37) Soh, C. H.; Chui, W. K.; Lam, Y. An efficient and expeditious synthesis of di- and monosubstituted 2-aminoimidazoles. J. Comb. Chem. 2008, 10, 118-122.

(38) Kumar, S.; Jaller, D.; Patel, B.; LaLonde, J. M.; DuHadaway, J. B.; Malachowski, W. P.; Prendergast, G. C.; Muller, A. J. Structure based development of phenylimidazole-derived inhibitors of indoleamine 2,3dioxygenase. J. Med. Chem. 2008, 51, 4968-4977.

(39) Jost, C.; Nitsche, C.; Scholz, T.; Roux, L.; Klein, C. D. Promiscuity and selectivity in covalent enzyme inhibition: a systematic study of electrophilic fragments. J. Med. Chem. 2014, 57, 7590-7599.

(40) Fortin, S.; Moreau, E.; Lacroix, J.; Cote, M. F.; Petitclerc, E.; Gaudreault, R. C. Synthesis, antiproliferative activity evaluation and structure-activity relationships of novel aromatic urea and amide analogues of N-phenyl-N'-(2-chloroethyl)ureas. Eur. J. Med. Chem. 2010, 45, 2928-2937.

(41) Bellina, F.; Guazzelli, N.; Lessi, M.; Manzini, C. Imidazole analogues of resveratrol: synthesis and cancer cell growth evaluation. Tetrahedron 2015, 71, 2298-2305.

(42) Ascher, D. B.; Cromer, B. A.; Morton, C. J.; Volitakis, I.; Cherny, R. A.; Albiston, A. L.; Chai, S. Y.; Parker, M. W. Regulation of insulinregulated membrane aminopeptidase activity by its $\mathrm{C}$-terminal domain. Biochemistry 2011, 50, 2611-2622.

(43) Kabsch, W. Acta Crystallogr., Sect. D: Biol. Crystallogr. 2010, 66, $125-132$.

(44) Adams, P. D.; Afonine, P. V.; Bunkoczi, G.; Chen, V. B.; Davis, I. W.; Echols, N.; Headd, J. J.; Hung, L. W.; Kapral, G. J.; GrosseKunstleve, R. W.; McCoy, A. J.; Moriarty, N. W.; Oeffner, R.; Read, R. J.; Richardson, D. C.; Richardson, J. S.; Terwilliger, T. C.; Zwart, P. H. PHENIX: a comprehensive Python-based system for macromolecular structure solution. Acta Crystallogr., Sect. D: Biol. Crystallogr. 2010, 66, 213-221.

(45) Emsley, P.; Cowtan, K. Coot: model-building tools for molecular graphics. Acta Crystallogr., Sect. D: Biol. Crystallogr. 2004, 60, 21262132.

(46) Jubb, H. C.; Higueruelo, A. P.; Ochoa-Montano, B.; Pitt, W. R.; Ascher, D. B.; Blundell, T. L. Arpeggio: A web server for calculating and visualising interatomic interactions in protein structures. J. Mol. Biol. 2017, 429, 365-371.
(47) Pires, D. E.; Blundell, T. L.; Ascher, D. B. mCSM-lig: quantifying the effects of mutations on protein-small molecule affinity in genetic disease and emergence of drug resistance. Sci. Rep. 2016, 6, 29575.

(48) Pires, D. E.; Ascher, D. B. CSM-lig: a web server for assessing and comparing protein-small molecule affinities. Nucleic Acids Res. 2016, 44, W557-61.

(49) Pires, D. E.; Blundell, T. L.; Ascher, D. B. pkCSM: Predicting small-molecule pharmacokinetic and toxicity properties using graphbased signatures. J. Med. Chem. 2015, 58, 4066-4072.

(50) Singh, V.; Brecik, M.; Mukherjee, R.; Evans, J. C.; Svetlikova, Z.; Blasko, J.; Surade, S.; Blackburn, J.; Warner, D. F.; Mikusova, K.; Mizrahi, V. The complex mechanism of antimycobacterial action of 5fluorouracil. Chem. Biol. 2015, 22, 63-75. 